\title{
WARS WITHIN THE FRONTIERS: ARCHAEOLOGIES OF REBELLION, REVOLT AND CIVIL WAR
}

\author{
Neil Christie
}

\begin{abstract}
Civil war is much documented by text, but far too little by archaeology. The later Roman world was one often afflicted by civil conflict and power struggles between rival emperors, generals and troops, and these all appear to have had serious impacts on communities, regions, economies and frontiers. In what ways though can archaeology offer a guide or additional insight into these many conflicts? Or are these wars intangible materially, despite their destructive human impact? This paper broadly considers the types of materials and evidence - from walls to coins - that might reveal something of the 3rd- to 5th-c. wars that damaged the Roman West in particular, and argues that much more weight needs to be placed on these internal traumas.
\end{abstract}

\section{INTRODUCTION}

His name, that is Antoninus, was erased by order of the Senate (that of Varius Heliogabalus remained), since he had held it under usurpation, wishing to appear to be the son of Antoninus... He alone of all principes was both dragged along and thrown into a sewer and hurled into the Tiber. This befell him as a result of the general hatred of all, which emperors must particularly guard against, seeing that those who do not earn the love of Senate, people and soldiers, do not earn a tomb. (SHA Heliogab. 17).

Although this emperor [Constantius II] in foreign wars met with loss and disaster, yet he was elated by his success in civil conflicts, and drenched with awful gore from the internal wounds of state. It was on this unworthy... ground that in Gaul and Pannonia he erected triumphal arches at great expense, commemorating the ruin of the provinces, and added records of his deeds, that men might read of him as long as those monuments would last. (Amm. Marc. 21.16.15).

Soldiers who have been so trained and exercised at their base, whether they are legionaries, auxilia or cavalry, when they come together for a campaign from their various units, inevitably prefer warfare to leisure in the rivalry for valour. No one thinks of mutiny, when he carries confidence in skill and strength. (Veg. Mil. 3.4).

Whilst civil war was central to the creation of Empire and to the affirmation of strong imperial rule in the first centuries B.C. and A.D.- from triumvirates to Actium and to the 'Year of the Four Emperors' in A.D. 69-its traumas and human impacts are rarely registered in the archaeological record. Arguably the evidence is almost all documentary and iconographic (numismatic and sculptural) and certainly, without the narrative sources, these major events, so core to so many historical analyses of Rome's social, political, and military development, might be almost invisible and even ignored. This may well overstate the case since, obviously, we can identify provincial annexations, foundations of colonies, military changes, and religious directives as consequences of new orders, but even here, without the texts, these events and material impositions could be viewed simply as responding to direct imperialism by a smooth-running state. Similarly, the creation and evolution of the imperial cult, whilst intimately tied to securing power and allegiance in contexts of upheaval (Octavian/Augustus at the start of Empire to confirm a divinely sanctioned role; Vespasian in A.D. $69 / 70$ to reinforce and stabilise his hard-fought position), do not speak directly of the consequences of 
civil strife. ${ }^{1}$ And, of course, we have documented purges of rivals, kin, generals and supporters (religious, military or social) by new or intended emperors - these too might be classed as 'civil conflict', but again leave no archaeological trace, unless we count instances of damnatio memoriae, where names or images of once accepted elites or imperial familial members are scratched, chiselled or blotted out. ${ }^{2}$

Civil war in its various guises - conflict and campaigns between emperor and usurper, between usurpers, between east and west emperors (of varied 'legitimacy'), between generalissimos and counts, between mutinous armies and the State, between breakaway provinces and governors, and caused by assassinations of generals, purges of bodyguards, the vicious exploitation of civilians by state forces, civil insurrections, and perhaps also banditry-is a feature, often a prevalent one, of the 3rd to 5th c. in both the West and East of Rome's Empire. Some, especially in the 4th c., gain as much documentary attention as those 350 years earlier, from chroniclers and poets alike. Arguably, these were less debilitating to the State than those of the 3rd c., which were, in their frequency and distribution, highly divisive, damaging and a sizeable drain on lives and resources. Patently, Rome did regroup, restore and endure, but the view stands of an Empire whose suicidal or blood-letting tendencies were never far from the surface, and were only partially kept in check by tougher imperialism, which in turn generated provincial discord with the core and a slow detachment from it.

Halsall and others point to the substantial manpower losses through civil wars won by Theodosius in the late 4th c., which must have destabilised the West and fractured the West Roman court's ability to sustain its internal controls; a much thinned frontier control thence created the openings through which non-Roman enemies started to push, whilst ineffective emperors chose entrenched positions. ${ }^{3}$ Imbalances exist though in modern assessments of the impacts of these civil wars, with some seeing Rome's long-term endurance as signifying how these internal conflicts were only temporary - if very bloody — bursts of destabilisation; ${ }^{4}$ yet internal damages and disunities may appear temporary, but can also be cumulative in their impacts. Whilst Drinkwater has observed how "barbarians did not often take advantage of internal wars", he also identifies how many scholars have overplayed the intensity and scale of barbarian raids in the 3rd and 4th c. especially, and have ignored the fact that some 'campaigns' against these non-Roman groups were small-scale actions, partly pursued by emperors and generals to gain legitimate and praiseworthy victories (to balance out the damages and bad press caused by civil strife). ${ }^{5}$

\footnotetext{
${ }^{1}$ On the imperial cult, see, in particular, Fishwick (1992) and (2002), who charts the fluctuating role of the cult and the input of emperors in the first two centuries A.D.-but with diminishing data subsequently; the epigraphy and actual sculpture from excavated cult temples confirm specific peaks, often to be associated with imperial needs to affirm (a generally new) authority. See discussion below on the later fates of imperial cult complexes. Much debate is available on Augustan imagery, but a valuable analysis comes in Elsner (1995) 15972 and 192-210. Too many books exist that cover the span of the Late Republic and earlier Empire in terms of politics, war and succession, but, besides Tacitus' and Suetonius' Histories, two colourful modern overviews are Leach (1978) and Greenhalgh (1975), and with Jones (1980), a compact and lucid review of Octavian to Augustus, and Morgan (2007), an excellent new appraisal of A.D. 69.

${ }^{2}$ See introductory quote on Heliogabalus. Key is Varner (2004), with an emphasis on defacings and reworkings of portrait sculpture. Regarding bloody removals of kin and potential rivals, the Roman emperors were on a par with Germanic kings, as brought out neatly in Merrills (2009), who explores the dynastic disputes and succession issues amongst the Vandal royalty of North Africa, with Huneric in A.D. 480/81 being especially brutal and thorough.

${ }^{3}$ Selection by Theodosius of his weak son Honorius as his western counterpart further diluted the battered western Empire: see general summaries in Mitchell (2007) 84-93 and by Curran and Blockley in Cameron and Garnsey (1998). On Theodosian victories and western debilitation, see comments in Ferrill (1986) 75-77; Blockley (1998) 426-30; and, most usefully, Halsall (2005) 48-49. On emperors and war in this period, see also the valuable summary in Lee (2007) 21-37.

${ }^{4}$ E.g. Elton (1996) 152-55, who seems not to trust claims of manpower shortages in the period towards $c a$. A.D. 400, but does note the claimed 54,000 Roman troopers lost in Magnentius' general's defeat at Mursa in 351; perhaps over 30,000 fell in Eugenius' defeat at the Fluvius Frigidus in 394. Elton offers useful overviews on the nature of usurpers and civil wars and talks of the tactics documented, including sieges - 193-98, 227-33but he in no way highlights these as on a par with barbarian impacts. Also on the natures of civil war/conflict, see Lee (2007) 66-73.

${ }^{5}$ Drinkwater (1996).
} 
There are problems in defining civil war in the latest phases of the Empire, of course, since in the 5th c., warfare against non-Romans was as much inside as outside or on the fringes of the Empire, and with many of these non-Romans, periodically at least, labelled and paid as federates or allies to fight for the imperial government - often against usurpers or insurrectionist groups viewed as working against the official state machinery. The Visigoths of south-west Gaul could even, in their shady federate status, dare to promote certain usurpers, though these usurpers might be viewed as more Roman to locals than the aggressive and never-seen emperor based in distant Italy, who might then send troops to bring even greater disruptions to their territory. Hydatius' chronicle, for the first half of the 5th c., is particularly busy in recounting the efforts and failures of the Goths as federates, alongside tracing Roman (Italian) campaigns against claimants such as Jovinus and Sebastian, to be matched by the moans of Prosper of Aquitaine, writing in the 430s and enumerating usurpers and intruders in the first third of the century. ${ }^{6}$ How we define civil war is matched by how we define the power groups and their relationships with the central state-indeed, in the context of 5th-c. coinages, King suggests that however we interpret the confusing issues of 'official' or 'unofficial' status (in our academic and historical eyes), "the answer lies in a more flexible approach to the definition of Roman and nonRoman in this period".

This paper, however, is not geared to seeking such definitions, or to contemplating further the depth of impact - short- and long-term - of civil wars on the late Empire and their contribution to the 'End'; rather, it aims to examine how far archaeology is able to trace civil war on its different levels, and whether its voice can contribute anything to an analysis of the textual evidence. The worry is that the traumas that must have been played out on battlefields, in camps, in sieges and towns, are largely lost to us despite the documented levels of upheaval and loss; as a result, it may be easy for historians and archaeologists alike to downplay the physical impact and even to doubt the damages inflicted on both military and civilian populations. ${ }^{8}$ Below, I examine a variety of sources of evidence to start the debate on archaeological visibility: first, town and other defences, to consider state responses to insecurities; second, memorials - from epitaphs to official representations and commemorations; third, numismatic guides to wars, usurpers and victories; and finally, the topic of reprisals or retribution, where a new power defaces and seeks to blot out depictions of the defeated. Most of the data deployed here are not clear-cut, and may be read in different ways; but it is better to ask different questions of these than to stick to a simple reading and explanation.

\section{WALLS}

First we turn to the most tangible of manifestations of later Roman insecurities. The erection of powerful urban defensive circuits in the western Empire and in Gaul, especially from the late 3rd c., and the shrinkage of urban spaces, in some instances of 'exposed' towns, are seen as fundamental components of a changing Roman world, and as reactions to growing external threats. New frontier works, the re-thinking and re-modelling of frontier control systems and of the Roman army in general,

\footnotetext{
${ }^{6}$ See Burgess (1992) on Hydatius and Muhlberger (1992) on both Prosper and the 'Gallic Chronicler' of A.D. 452, whose emphasis, Muhlberger argues, is geared more to observing the dismemberment forced by external forces in the West. See also Kulikowski (in this volume). For 5th-c. civil wars, see Ward-Perkins (2005) 43-49, highlighting how "As in other periods of history, failure against foreign enemies and civil war were very closely linked, indeed each fed off each other". Ward-Perkins singles out the long, but ineffective reign of Honorius as enabling the West's dismemberment. He makes little comment on 3rd- and 4th-c. civil conflicts. See Faulkner (2000) 168-74 and Snyder (1998) 95-99 on the main British usurpers/tyrants-Magnus Maximus and Constantine III.

7 King (1992) 195, who observes how indeed "It is virtually impossible to assign the coins... to either locals or barbarians given the nature of the evidence" - however, whether we try to label these as local/ barbarian/ official/ unofficial, the coins are unarguably efforts at a continuity of Roman forms and monetary display.

${ }^{8}$ In part, the problem is matched by the general invisibility of archaeological data for some of the major plagues documented in the Roman and Byzantine epoch — see comments in Christie (2006) 500-504 on the socalled Justinianic plague of the A.D. 530s.
} 
plus a revised emphasis on key (military) highways linking inner capitals to the frontier zones, add to the general image of change, and of efforts to preserve the whole Empire. ${ }^{9}$

But the emphasis is all too often on the threats beyond the Empire's frontiers. Thus, in Stephen Johnson's invaluable volume Late Roman Fortifications (1983) - which surely merits a second edition to take on board so much new archaeology of defence-it is noticeable how civil conflict within the Empire plays merely a bit part in his narrative of cause and effect, with the emphasis very much on the external, non-Roman threats. ${ }^{10}$ Thus: "The Gothic raid of 267 came as a concerted culmination to a series of inroads made by the Goths from about 238 onwards. Spasmodic pressure on the Danubian frontier and on Thrace had been met by a succession of 3rd-c. emperors, sometimes by cash subsidies (in effect payment to keep the peace) and sometimes by the withdrawal of this courtesy, and consequential further raids. Sustained resistance to the Gothic pressures was not assisted by the instability of the imperial office". ${ }^{11}$ Johnson's maps pinpointing the distribution of 3rd-c. coin hoards show the latter gathered around the imposed lines of arrows which the captions label as 'General direction of Barbarian invasions with dates'; hoards thus were panic responses to non-Romans according to Johnson, who effectively excludes the panics equally induced by Roman civil war and movements of Roman troops, and excludes the possibility that the hoards represent savings by Roman troops gathered in those spaces, or savings lost or given up as new coins with changed imagery- on the latest 'official' coins - took over in circulation. ${ }^{12}$

Fig.1 The canal defensive walls at Aquileia in north-east Italy. The multiple defences at this imperial city are assigned to various historical dates, many tied to civil war episodes. The image shows spolia as the main wall fabric, perhaps indicative in this instance of rushed works in advance of expected assault. (Photo: Neil Christie)

There are urban sites and defences that have been associated closely with reactions to impending or actual civil war. The key example is Aquileia, a major port city, and imperial stopover at the head of the Adriatic in north-east Italy. Aquileia has seen extensive excavations since the early 20th c., including of its defensive curtains, some of whose phases and builds remain exposed. The various excavators have sought to identify defences - which overall span Republican to Byzantine times - to match some of the key moments in the city's history. ${ }^{13}$ Thus we are informed of circuits tied to 169 B.C. and the Roman colony; A.D. 168 - the Marcomannic assault; A.D. 238-civil war destruction/siege; 290/300 — a revised imperial status; 361 — civil war siege; 394-stopover point for Theodosius I; 452-Aquileia's destruction by the Huns; 490 - siege by Theoderic; 556 - a Byzantine restoration.

\footnotetext{
${ }^{9}$ Poulter (2007a) provides one very full example where the emphasis is on Rome against the outsiders: the Danube provinces and frontiers see significant changes in the 4th to 6th c. within the army, but especially in terms of fortifications and their design, content and supply. It is noticeable how minimal the comments are here on the impact of civil wars in this same period in the regions analysed-but this is as much due to the archaeological emphasis on the frontier line and on the related evidence. Poulter (2007b) 30, for example, notes the set of 5 Diocletianic inscriptions of A.D. 298/99 from Moesia II province, each recording pro futurum in aeternum rei publicae praesidium constituerunt: these defences refer to a securing of the line and the province, but arguably they also recall the need to secure the Empire/Republic internally.

${ }^{10}$ Chapter 4 of Johnson (1983) has a very telling title: 'The pressures on Rome: barbarian invasions and tactics'. In this, significant internal disruptions such as the rise of the Gallic Empire on imperial soil are commented upon more in terms of opening up access to the Empire for new barbarian raids, which Johnson perceives as the more damaging to the West, even though the civil wars probably extinguished far more soldiery. Too often Johnson speaks of 'invasions' or refers to war bands, implying a high numerical scale, although in many 3rd- and even 4th-c. instances, these were probably rapid and thus fairly small-scale raiding parties, exploiting voids created by distracted Roman forces. On the possible sizes of such raiding forces, see Elton (1996) 72-73, plus 48-54, and on the artificial (Roman and modern) inflation of their threat, see Drinkwater (1996), developed much more fully in (2007).

11 Johnson (1983) 73. Witschel (2004) 256 points to the over-emphasis by modern commentators on barbarian impacts in 2 nd- and 3rd-c. contexts.

12 Johnson (1983) 71, 75, figs. 23 and 24.

${ }^{13}$ Summarised with related bibliography in Christie (2006) 291-94. See Christie (2006) 322-24 for discussion of spolia in city walls, identifying varied uses and displays, whether practical, ornamental and/or symbolic (these valid for spolia usage in other contexts, such as in churches - Christie (2006) 130-33).
} 
Should major documented events always equate with major structural responses? Arguably, there is too much effort to achieve this, when in reality some of the building works are of longer gestation. Thus, for the siege of Maximinus the Thracian in A.D. $238,{ }^{14}$ the use of artillery by both defenders and attackers (with women inside Aquileia cutting their locks to provide strings for bows and catapults) indicates a defended city, but was this via rapidly built new walls, or a modified old Republican circuit, itself perhaps hastily restored after the Marcomannic and Quadic incursions into north-eastern Italy in the 160s? The insertion of both imperial palace and circus in the western quarter, in the Tetrarchic and Constantinian period, is then linked to the addition of various projecting towers (pentagonal, octagonal, polygonal) on the wall circuit. Most evident is the spolia-laden canal/riverside circuit with towers (fig. 1), featuring re-used inscriptions and architectural material thought to come from buildings demolished (or already ruinous from other sieges!) to help build and defend the 4th-c. townscape.

A further, later wall divided the old city in half, running through the ruinous forum-basilica and rejecting the old monumental and imperial zones, but enclosing the core religious buildings, including the memoria of S. Ilario, built ca. A.D. 400. Spolia incorporated in these defences relates to buildings demolished by the end of the 4 th $\mathrm{c}$., and with one partial inscription recording a likely emperor (Theodo...) and Praetorian Prefect Hilarianus, in charge of restoration of works and walls; as the prefect is identified with Hesperius Hilarianus, son of the poet senator Ausonius, and in office in Gaul and Italy in the 380s, so the claim is that Theodosius the Great prompted defensive renewals or modifications at Aquileia, perhaps in the wake of the defeat at Adrianople, or after defeating Eugenius.

As stated, it is slightly incautious to attempt to tie walls in too closely to such documented events and names ${ }^{15}$ although an exposed and important city like Aquileia will undoubtedly have been forced to respond structurally - in terms of defence and repair of walls, buildings, population displacement - to both Roman and non-Roman assails. It is also problematic to claim that strong (although clearly not always effective) defences could be raised at speed. If advance warning was good and an army at hand - as would be valid perhaps for a major city like Aquileia - then rapid response is feasible (such as refortifying or bolstering walls in a month or so), but with much necessarily brutal treatment of public and other structures to procure sufficient materials for both the core and the face of walls. Such may indeed be evident in the canal curtain, and this fits better a context of potential siege warfare, which would only be expected from an alternative or rebel Roman army.

Elsewhere in Italy, other defensive measures by key towns can fit equally into the context of internal instability, and in the case of Verona, the use of spolia in a curtain wall documented to A.D. 267, in the reign of Gallienus, contrasts with the ordered and more expansive Aurelianic walls of Rome, whose form and scale signify a longer programme of construction. 'Barbarian' incursions, notably by the Iuthungi/Alamanni, did hit Italy in the 260s, but just as important for Gallienus was the ongoing and fluctuating conflict with the so-called Gallic Empire, headed by Postumus. ${ }^{16}$ We cannot exclude that both usurper and emperor began to secure strategic centres with walls as physical manifestations of the drawn-out power struggle (see also below on Britain): a rival Roman army would cause far more damage than swift Alamannic raiding parties, and establishing fortified urban strongholds where troops might be billeted and food supplies stored-or where civilians and administrators might find security while the military forces were elsewhere-makes major sense, even if the logistics of undertaking such measures would have been arduous at best in the timeframe. ${ }^{17}$

\footnotetext{
${ }^{14}$ Herodian 8.3-4.

15 See useful comments in Fernández-Ochoa and Morillo (2005) 300-301, 316-27 on dating, typological analyses, structural variances and related questions in connection to Late Roman circuits in Spain in particular. Rambaldi (2009) 122-28 offers an Empire-wide assessment of defensive building works in the 3rd-c. anarchy period, although the related catalogue shows that dating of some circuits is often made by association with historical events, especially invasions, rather than through secure archaeological chronologies - though rarely will pots or coins prove a construction date.

${ }^{16}$ Rambaldi (2009) 127 and catalogue entries $168-88$ for likely later 3rd-c. walls in North Italy, preferring to emphasise these as responses to the "più massiccia invasione di Alamanni e Iutungi".

17 In this context, a first appearance of a modified Roman army in terms of greater mobility — both in cavalry and particularly in field units - and in provision of bodyguards for emperors, is logical, as 'Gallic' and 'Roman' usurpers and emperors roved to meet rival threats and external raids; Gallienus is suggested by some as the
} 
Rome's defences certainly can be read in like fashion: a key political and civilian centre, secured in line with a new policy of fortification, prompted by upheavals of civil war and external barbarian raiding. This marks the start of a formal process of defensive investment in cities in the West, developed under the Tetrarchs and Constantine. ${ }^{18}$ Potentially, therefore, walls first appear as expressions of new security, or of efforts to maintain control, with an emphasis both on key strategic urban seats, but also on significant population foci-the threat being real or perceived; with stability resumed, this process of strengthening urban defences is extended outward, in recognition of the value of such secure bases for populations, food and troops.

Fig. 2 A 19th-c. engraving of Burgh Castle wall and circuit tower, one of the Saxon Shore fort installations active by the final quarter of the 3rd c. (From: Knight (1845)).

Perhaps one of the more secure linkages between urban and military defence and Roman civil war is evident in Roman Britain towards the end of the 3rd c., in the wake of the collapse of the 'Gallic Empire' and Britain's continued separation from 'official' Roman rule. Here we can trace extensions and reinforcements to the series of coastal bases and depots labelled the Saxon Shore forts, extending from the central south coast base of Portchester to at least Brancaster in Norfolk, or further north still, to Skegness and Brough-on-Humber (fig. 2). ${ }^{19}$ Some of these belong to the early 3rd c. or earlier, and may have served as shipment points, depots, fleet bases for military campaigns, such as under Severus, and as simple supply bases for the forts and towns of the interior; forts at these sites and accompanying walls were thus intended to define military units and defend supplies.

But reversion to defences and new installations can be identified for the A.D. 270s onwards, at seats like Richborough (a new fort replacing a signal-tower), Dover and Portchester, and the temptation has been to link these works with the name of the rebellious general, Carausius, dominant in Britain and on the near continent from A.D. 286, until he was murdered and replaced by his minister Allectus in 293, who endured until $296 .{ }^{20}$ Both were viewed as usurpers, and both were active in issuing coins, but both sought recognition for long spells-hence many of the issues of Carausius duly found in the earliest layers of the Shore forts depict him alongside the more easterly imperatores (and 'brothers'), Diocletian and Maximian. The recent excavations at Pevensey, meanwhile, have uncovered timber foundation piles to the south curtain wall, dendrochronologically attributable to A.D. 280-300, but with associated coins of Carausius and Allectus, tying the fortress to A.D. 293.

As noted, some forts were earlier in date, and some seem to show fair activity in the 270 s, as at Portchester, Bradwell and Lympne (such as with coins of Tetricus), which might even be an indication of military provisioning and entrenchment during the Gallic Empire - and not just reactions to possible largely undocumented seaborne raids along the Channel coasts by Saxons and others. The efforts at Pevensey in 293 should certainly indicate expectation of a seaborne attack, and the form of the defences here, as in the other 'new' forts, are observed as of a scale to counter siege, which was not a likely tactic of any small-scale raiding force. ${ }^{21}$ Magnus Maximus and other mid- and later 4th-c. British usurpers may well have utilised the forts again in their stands to gain the purple, but more as launch-pads for campaigns on the continent, and for securing rearguard supplies; otherwise their role

author of this new military template, later formalised under Constantine or Diocletian: Southern and Dixon (1996) 11-14; Whitby (2004) 160-62; Tomlin (2000) stressing the small sizes of the new field units/legions. On later Roman military equipment, see also Bishop and Coulston (1993).

${ }^{18}$ Urban and wider defensive processes in Late Roman Italy are examined in Christie (2006) 294-348 with related references. For wider patterns, refer again to Johnson (1983); for Spain, see the careful review by Fernández-Ochoa and Morillo (2005), who pinpoint a first phase of urban defensive reconfiguration under the Tetrarchy (327-29) centred on the north-west of the province.

${ }^{19}$ Pearson (2002) provides the most recent review of functions and chronologies to the Saxon Shore forts.

${ }^{20}$ Coarelli (1999) 32-33 notes the references in panegyrics to Constantius and to Maximianus first to victory and restoration of Britannia, and then to glorification of the naval victories in the East and West through displaying the prows of conquered vessels (i.e. of Carausius) on the Rostra in the Roman Forum.

${ }^{21}$ Pearson (2002) 56-64 and 125-38 reviews the dating evidence and context; see 136-37 on 'Defence against Rome'. Johnson (1983) 211 is more hesitant, saying that arguments to tie Carausius to fortification works "to secure his position after his usurpation... do not carry conviction", although, as in (1979) 111-14, he is happy to see Carausius exploiting and perhaps then upgrading pre-existing defensive bases after his usurpation. 
against external threats-Saxons, Franks and others - was heightened in the 4th c., as marked by the provision of new signal towers along the north-eastern and western coasts of the province.

Alongside the military coastal bases, we might question whether politics and civil war affected also urban contexts in Britain, most specifically at the governor's capital of London. Both new work and re-assessment of old excavation data from London, and specifically at and near Newgate, identify a re-modelling of the city walls in the second half of the 3rd c., reinforcing the earlier and substantial stone circuit of $c a$. A.D. 190-225; the re-modelling more generally included provision of the riverside wall as well as of bastions and re-cut ditches. ${ }^{22}$ Whilst this review prefers not to see the first circuit as tied to the name of the governor Clodius Albinus (A.D. 193-97) in resistance to Septimius Severus, and argues for an extended building campaign, the later 3rd-c. work remains linked to historical events from our few textual guides - "at a time when Saxon shore raids were becoming more frequent". 23

Maloney earlier flagged the evidence from Shadwell, $1.2 \mathrm{~km}$ east of London, indicative of a signal station and tower of $8 \mathrm{~m}^{2}$, which coin-finds identify as strongly active in the 280s and 290s, and with usage enduring perhaps until the mid-4th c. ${ }^{24}$ Some coin issues at Shadwell go back to the 260s, and fit well with the revised dating of the riverside wall to A.D. 255-70; whilst this pre-dates the famous names of Carausius and Allectus, it does fit the wider context of the Gallic Empire and of upheavals and change active on the continent. Effectively, the generally imprecise evidence from London (as elsewhere) can currently be read in a variety of ways, either to fit an historical context or more than one, or to 'float' and provide a patchwork image without being part of a rigid chronological system. But, since defensive works for some towns can be fairly securely attested in northern Gaul from $c a$. 270, a contemporary programme of fortification or reinforcement across the Channel at key sites is equally logical; a riverside wall at London in the 260 s would fit the wider network of provincial security measures being instigated, in response to both civil war and heightened external threats. ${ }^{25}$

A contrast with the Saxon Shore forts, which were not disbanded following their likely role as a protective naval and supply cordon for Carausius and Allectus, can be made with the Claustra Alpium Iuliarum, established in the 4th c. across the north-east line of the Alpine chain, as a control and guard to access into Italy from the Danubian territories. Discussed more fully elsewhere, this military command comprised a network of road forts and associated valley walls and watchtowers, plus new legionary units, designed to observe and channel movement along key and lesser pass routes. The principal centres included pre-existing towns with revamped defences set near, rearward, or in advance of the defensive core, notably Castra (Ajdovščina), plus new forts, such as Ad Pirum (Hrušica), overseeing specific route-ways. ${ }^{26}$ Text and archaeology combine well to indicate that the Claustra functioned fully perhaps only between ca. A.D. 310 and 395, and were exploited or misappropriated mainly for conflict between rival emperors, the best documented being the clash between Eugenius (plus general Arbogast) and Theodosius in the Julian Alps in September 394, which

\footnotetext{
${ }^{22}$ Lyon (2007), en route reviewing previous publications on London and its walls by Norman and Reader in the early 20th c., plus, from the 1960s to early 1990s, Merrifield, Maloney and Perring in particular. For the 3rdand 4th-c. works, see 46-52, with the main emphasis on the bastions which belong mainly to the mid 4th c., although some can be shown now to have been medieval additions.

${ }^{23}$ Lyon (2007) 52.

${ }^{24}$ Maloney (1983) 104-105. For wider discussion of Romano-British town defences, see Hobley (1983).

${ }^{25}$ City walls in northern Gaul: Mertens (1983); and the wider review of the Gallic and Germanic provinces by Johnson (1983) 82-117; Knight (1999) 26-34, noting only Grenoble with a date secured by inscriptions to Diocletian and Maximian. For a summary of studies on defences in Aquitaine, see Christie (1997). Chronologies for the defences remain much debated, with work further south in Gaul, such as that at Le Mans and Tours, preferring wall construction dates in the first half of the 4th c., and sometimes even as late as the mid 4th c., as recently proposed for Tours, whose compact circuit included the amphitheatre: Galinié (2007) 247-55, 359-61. As noted, for north-west Spain, Fernández-Ochoa and Morillo (2005) 331-39 argue for a first significant phase of urban defences at key centres under the Tetrarchy, and in fact "situate the construction of the first wall-circuits in Spain within this historical context [securing troop and supply movement], connecting fortification programs in Gaul and Britain with the contemporary phenomenon in Spain" (339). The authors hold back, however, from connecting these acts to the Gallic Empire, to Carausian efforts, to state efforts against Carausius, or to works in the aftermath of such civil conflicts. Again, the archaeology does not enable any such historical precision; we await suitably explicit epigraphic guides.

${ }^{26}$ An overview is offered in Christie (1991), but with the archaeology detailed by Ulbert (1981) for Ad Pirum.
} 
saw terminal destruction to a variety of installations (and manpower); but, other actions between Roman forces are documented for 352 (Magnentius versus Constantius II), and for 388 (Magnus Maximus versus Theodosius), with possible traces of these evident in Ad Pirum's archaeology. ${ }^{27}$

The Claustra may well, therefore, have been disbanded as a formal military defensive system as a result of these internecine struggles, even if the defended towns persisted as depots, civilian bases and occasional billeting points. However, it appears that the Claustra were not re-activated when Stilicho was endeavouring to deal with the Gothic forces of Alaric in the last decade of the 4th c. and first decade of the 5th, when reliance was more on combining troop numbers (including of course those troops removed from the Rhine and from Britain), tracking the enemy, and selecting occasional pitched battle - with, as is well known, variable results (for Stilicho, Alaric and Rome). ${ }^{28}$

\section{MEMORIALS}

A defaced memorial in the Rome Forum bears witness to Stilicho's fights and fates in external and internal conflict (fig. 3). The stone (and now long lost statue), set up under the city prefect in A.D. 405 , records, in good quality script, the victorious harrying and defeat (albeit not wholesale) of Gothic forces on Italian soil in 402 and 403 - the text celebrates and (rather anxiously perhaps?) emphasises the 'fidelity and valour of the most devoted troops'. But subsequent failures to trap and destroy Alaric and his Visigoths, claims of collusion with this enemy, and losses incurred through the invasion of Radagaisus in 405/406, saw the Emperor Honorius order the arrest and execution of his general (and son-in-law) in 408, plus a purge of Stilicho's German bodyguard and other non-Roman units (as well as some unfortunate secular Roman officials). Some of these soldiers (an estimate is of 20,000) escaped to join Alaric, who in 410 finally entered and sacked Rome; these ex-Roman soldiers and bodyguards may even have seen that their former commander-general's name and honours had been chiselled out of existence on that same dedicatory stone in the Forum. ${ }^{29}$

A memorial, arguably, both to civil war and its human losses and impacts, as well as to frontier traumas and enemy plundering, is encapsulated in the much debated Augsburg altar dedication of A.D. 260/61, commemorating a victory against Iuthungi and Semnones by the provincial governor Genialis. ${ }^{30}$ This was no powerful legionary force in victory, however, as we are told that Genialis' forces were a mix of Raetian troops, one body from one or both of the German provinces, as well as local recruits, either conscripts or local volunteers (populares-perhaps citizens protecting their lands). The scattered composition and the recourse to populares to bolster the regular soldiery reflect how the conflict with external enemies came in the midst of internal strife, since, as Drinkwater has recently argued, Genialis had declared in favour of the new 'Gallic Emperor' Postumus, who was elevated to the throne in 260. Genialis may well have gathered together both Raetian and German provincial and frontier troops to deal first with the returning Iuthungi, and then to offer his arms and services to Postumus. The latter, however, failed to exploit this offer, only for Gallienus to take back a rebellious Raetia and to remove Genialis.

The inscription shows the erasure of the names of both Postumus and a related Honoratianus - damnationes memoriae of vanquished usurpers - and of the Raetian army. A further element to note is the delay of Gallienus in dealing with both Iuthungian and Raetian threats, due largely to the usurpations in the Balkans of two other claimants, Regalianus and Ingenuus. Delays cost Rome dear, therefore: Iuthungi able to raid deep even into north Italy (the inscription records 'several

${ }^{27}$ Ulbert (1981) 42-49 on these destructive episodes. On manpower losses, see below.

${ }^{28}$ Papers in the excellent conference volume edited by Buora (2002) utilise militaria-military equipment items - to explore not just dress and identity, but questions such as the militarisation of the landscape, garrisons, and provision of defensive posts. Cavada and Župančič, for example, attempt to tie fittings with the Rhenish and British troops summoned by Stilicho to defend Italy; Bolla, meanwhile, suggests some finds from the Lake Garda zone may help document both external/barbarian raids and even civil conflicts. The volume is reviewed by Christie in JRA 17 (2004) 699-705.

${ }^{29}$ Claridge (1998) 84 notes how sockets remain on the stone to show the placement of the lost statue of Stilicho; she adds that the pedestal was in fact a re-used "old equestrian statue base set on its end".

${ }^{30}$ Drinkwater (2007) 53-61 offers a detailed contextualisation of the stone; its discovery and inscription are discussed fully in Bakker (1993), whose chronology for these events is slightly earlier than Drinkwater's. See also Carroll (2001) 132-33. 
thousand' Italians who were released by Genialis' victory - though with many no doubt also killed in Italy or at the battle), Genialis denuding the German limes, Postumus establishing himself as a lasting threat in the West, and then the full evacuation of Upper Germany. ${ }^{31}$

There are only occasional tombstones which provide a context for the loss of life, by soldiers in particular, in the 3rd and 4th c., and which testify to war, on and well within the Empire's frontiers. Two epitaphs linked by location relate to the 4th-c. fortified bridgehead at Deutz (Roman Divitia), opposite Cologne, in Germania II province on the northern Rhine: the first, probably of the mid 4th c., records the soldier and protector Viatorinus, perhaps officer to the mounted scouts stationed there, who was killed by a Frank on barbarian soil near his fort. The second is another protector (senior centurion), one Florius Baudio, ex ordinario leg(ionis) II Ital(icae) Divit(ensis), who was killed in the campaigns of, and advanced through Italy led by, Constantine in A.D. 312, en route to face Maxentius at Rome; his son, also in the unit - which may have been a select detachment from the Divitia fortburied Baudio at Spoleto. Two other Divitian soldiers who died on the same campaign were buried in Otricoli and at Rome. ${ }^{32}$

Fig. 3 Dedication in the Rome Forum set up by the city prefect Pisidius Romulus in A.D. 405. Above the SPQR, the two lines which formerly heralded the name of the magister militum Stilicho have seen damnatio memoriae imposed following the Emperor Honorius' execution of his general in A.D. 408. (Photo: Pauline Carroll).

Whilst the previous examples range from a generalissimo to governors and to soldiers, one of the most tangible and best studied (and most debated) memorials to late Roman civil war is the Arch of Constantine, sited between the Colosseum and the much older (but equally inspiring) Arch of Titus, with its own images of victory, spoils and triumph. ${ }^{33}$ Constantine's arch commemorates in large measure victory against a fellow Roman, an established emperor at Rome, Maxentius, who contributed much to the Eternal City's urban and monumental fabric, yet who was suitably framed as a 'tyrant' (not former colleague) as Constantine marched on and conquered Rome. ${ }^{34}$ The Arch is recorded as being set up in A.D. 315, in honour of Constantine by the Senate and people of Rome, on the occasion of his decennalia or tenth anniversary (since his proclamation, and thus, at the outset of his civil war actions, rather than following his capture of Rome).

Whilst matching the arches and displays of earlier emperors such as Titus, Trajan and Severus, and whilst repeating some of the imagery in terms of captured barbarians and winged victories and of adventus or triumphal entry and procession, the narrow horizontal friezes above the side arches portray episodes key to Rome's restoration from the tyrant - such as the advance from Milan, the assault and capture of Verona (fig. 4), and the battle at the Milvian Bridge. 'Borrowed' or re-located panels of Trajanic, Hadrianic and Marcus Aurelian date are viewed now as allying or equating the new western emperor with glorious imperatores of the past, duly reinforced by instances of Constantine's head replacing those of these 2nd-c. emperors. As Elsner emphasises, the totality and syncretism of the new and the (modified) old in form, fabric and detail make the Arch (presumably its design had been approved and perhaps enhanced by the emperor himself) a powerful and symbolic statement of renewal as well as continuity: "The specific inauguration of Constantine's campaign to overthrow Maxentius, and its setting in parallel with Trajan's Dacian Wars, is valorized by the broader picture of Roman imperialism - the conquest and maintenance of the provinces - that is implicitly made possible

${ }^{31}$ Drinkwater (2007) 56-57 and 61-62 arguing down the numbers of captives to the high hundreds. On the Gallic Empire as a whole, see Drinkwater (1987), and with useful elements also in Knight (1999). Useful views on the evacuation of the former Upper Germany limes zone and the nature of the enemy are in Witschel (2004) 270-71.

${ }^{32}$ See Carroll (2001) 136 with colour pl.22 and Tomlin (2006) 61, citing ILS 2777 for Baudio and CIL XI 4085 and ILS 2346 for the two other felled loyal Constantinian troopers. Carroll-Spillecke (1997) 148, however, identifies the pre-Constantinian origin to the Divitenses, implying an original fort base elsewhere.

${ }^{33}$ On the Arch of Constantine, a compact and current summary is by Liverani (2005), but with fuller discussion and bibliography by Elsner (2000), examining the imagery and meanings in detail; see also the brief but useful comments in Cameron (2005) 24.

${ }^{34}$ On Maxentian and Tetrarchic works in Rome and other capitals, see Rinaldi Tufi (2005); for Tetrarchic works in Rome, see Coarelli (1999). Maxentius as builder and restorer with grand designs is flagged by himself on coin issues as conservator urbis suae. 
by such hard but responsible choices as that of Constantine to make civil war against... 'tyranny' ". 35 This is, therefore, a monument to legitimacy.

Fig.4. The Arch of Constantine, Rome - view of the south face, left entrance arch, depicting the siege by Constantine's troops of Verona (or Susa) in north Italy; above are two of the roundels of Hadrianic date. (Photo: Neil Christie).

We might also note an important predecessor to Constantine's Arch (or the Senate's Arch to Constantine) in Rome's forum, which likewise exploited spolia in symbolic fashion to commemorate a restored empire. The arcus Novus was a Tetrarchic victory monument erected most probably in A.D. 303 as part of the decennalia and vicennalia celebrations of the emperors, and including as a presumed centre-piece, the triumph over the usurpers Carausius and Allectus in Britain. What seems evident is that this employed materials culled from the Arch of Claudius-itself of course commemorating a British triumph - of A.D. 51/52. ${ }^{36}$

In effect, Constantine's Arch was in line with a new practice of merging old and new, and showing how holding together the Empire, through dealing with usurpers or enemies of a 'just' state, was as valid a victory as defeating the enemies over the frontiers. Hence the victory monuments proudly erected in the reign of Constantius II as recorded by Ammianus Marcellinus (see introductory quotes) — of which only the so-called 'Pagan Gate' (Heidentor) at Carnuntum-Petronell on the Danube frontier survives. ${ }^{37}$ Mayer has provided an excellent overview of some of these Late Roman victory monuments recounting and also depicting conflict against fellow Romans - though often in union with victories gained against proper barbarians - and questions how their words and images were perceived. ${ }^{38}$ Mayer highlights how legitimacy of rule was key to monuments of later civil conflict, most notably those erected in honour of Theodosius in Constantinople in the last two decades of the 4th c.; he quotes Pacatus, whose panegyric of A.D. 389 refers to justified imagery of defeated rivals, in this instance Magnus Maximus:

It is important to the security of every age for what has been done to be seen so that if anyone has ever entertained any nefarious desires, he may review the monuments of our times and drink innocence with his eyes. ${ }^{39}$ (Pacatus, Pan. Lat. 2 (12) 44.5-45.3 (trans. Nixon and Rodgers (1994) 512).

The spiral column of Arcadius celebrating the victory of the East over a rebellious Roman general in A.D. 400, the Goth Gainas, was arguably the most explicit visual statement of conflict between Roman forces, but again with the emphasis visually placed on legitimacy-hence, on the main column itself, Arcadius is depicted on the lost column frieze as seated alongside the western Emperor Honorius, with soldiers ranged up either side, whilst battle rages above, and on the base the two are shown on three sides. ${ }^{40}$

Brief comment may also be made of the changing character of triumphs, recently analysed by Beard, who highlights how victory monuments in the first centuries A.D. were closely tied to imperial triumphs, comprising processions of victorious soldiery, with captured booty and prisoners, and the returning emperor - all neatly displayed in the art of the Arch of Titus. In the Late Empire, there was a transition to ceremonial arrivals (adventus), with related games and processions, not necessarily linked

${ }^{35}$ Elsner (2000) 173, 163-75 analyses this use of 'past and present'. The attic inscriptions refer thereby to a 'just' use of army and weapons. However, it is important to recognise, as Mayer (2006) has argued, that the Arch of Constantine and an anonymous panegyrist do make reference to victory over northern barbarians too. Compare Drinkwater (1996) 26, highlighting how many a 3rd- and 4th-c. emperors had to have a convenient or more appropriate barbarian victory to impress both state and provincials.

${ }^{36}$ Coarelli (1999) 26-27, 31-32.

37 Jobst (2002) identifies the varied chronologies proposed for the 'Pagan Gate', but confirms from the spolia - re-cycled brick, tile and stone, notably 22 altars from nearby sanctuaries, including one dedicated by the local XIV legio to Iupiter Optimus Maximus - and from finds excavated at and around the arch, a mid 4th-c. date. The exploitation of the altars as building materials is postulated as an aggressive Christian policy against the old cult spaces at the fort and town.

${ }^{38}$ Mayer (2006).

${ }^{39}$ Mayer (2006) xx-xx. Translation from Nixon and Rodgers (1994) 512 of Pan. Lat.2 (12) 44.5-45.3.

${ }^{40}$ Mayer (2006) xx; Liebeschuetz (1991) 273-78; Lee (2007) 46. 
to actual victories. Far less scope existed for display of enemy booty, as often campaigns against nonRomans were on Roman soil and may have seen the re-capture of Roman goods and people (as with the Augsburg inscription noted above); exceptions were the triumphs held for Aurelian and Diocletian. Far more scope existed to display the heads of vanquished usurpers - as with that of Maxentius by Constantine. The adventus became more of a display of rulership and authority than of victories. ${ }^{41}$

\section{MONEY}

Money can act as a guide to later Roman civil conflict on a variety of levels: (i) first in terms of inflation, counterfeiting, weakened metal content and size as indications of internal politico-military and economic upheavals preventing production and circulation of and access to standard types; (ii) hoarding to signify either threat and panic and lost wealth, with the possible death/murder/flight of the owners reflected in the failure to recover the money, metal and other items, or hoards to signify avoidance - e.g. of tax-collectors, of looters (military or civilian), or of ties to failed usurpers and emperors, where the coin issues might implicate the owner; (iii) imagery and legends on coins to guide us on names of potential usurpers, some unknown to extant written sources, and on the propaganda of victory, appeals to gods, to unity, to harmony, etc.; (iv) savings and hoards to indicate owners and their allegiance or conflict with the State or with figures of power; and (v) coins as bribes/tribute to enemies and allies, and as donatives to supporters and soldiers.

For the latter, the reinterpretation of the early 4th-c. hoard of gold and silver coin, jewellery and silverware found near Beaurains (Arras, near Calais) in 1922 is significant. This material included the famous so-called 'Arras Medallion', depicting Constantius' triumphant entry and relief of a supplicant Londinium in A.D. 296- this the formal numismatic resumé of an imperial Roman recapture of a breakaway province (the legend on the reverse records the 'restorer of the eternal light'). ${ }^{42}$ This medallion is, with others in the hoard, a special record and keepsake of the owner's military life. From graffiti etched on the latest medallion, ownership appears to have been both that of Vitalian, protector, and, probably, his father, Valerian, whose name appears on a ring with his wife's, and who may have accumulated the older portion of the hoard. The coin issues and medallions appear to denote donatives, special payments made to troops and staff at the start or end of campaigns, or at victories or imperial anniversaries; key dates in the hoard are 297, 303 and 310. The need to tie army and senior commanders to an emperor in the 3rd c. and beyond appears to be borne out in the numismatic record, indicating donatives and especially the medallions as more 'regular' displays and bestowals from the reign of Gallienus. ${ }^{43}$

Fig.5 AR antoninianus of Postumus (259-68). 19 x $23 \mathrm{~mm}, 3.13 \mathrm{~g}$. Mint: Mint city I (Treveri [Trier]), 1st officina. Struck: 1st emission, 1st phase, AD 260. Obv: IMP C M CASS LAT POSTIMVS P F AVG Radiate, draped, and cuirassed bust right. Rev: SALVS PROVINCIARVM River god Rhinus reclining left, resting right arm on forepart of boat left in background, cradling reed in left arm, which rests against urn to right. The river god and warship may well symbolise the riverine and maritime strength of the 'Gallic Empire'.

Ref: Mattingly-Sydenham, RIC 587 corr. (obv. legend); AGK 87a; Cunetio 2367

(Source: http://classicaleconomies.com/mil_anarchy.shtml)

${ }^{41}$ Beard (2007) 321-28. On the Arch of Titus, see 43-45. Amm. Marc. 16.10.1 viewed Constantius II's visit to Rome in A.D. 357 as "an attempt to hold a triumph over Roman blood"-but with the historian eager to find fault with this Christian stranger to the City. On imperial victories and media of display, see also Lee (2007) 37 50. On imperial or 'official' art and its forms on the arches and columns, see Reece (1999a) 19-31.

42 Abdy (2006) 55-56; Tomlin (2006) 59. The catalogue entries 11-59 in Hartley et al. (2006) 122-31 cover the Arras hoard; items 18 and 19 (illustrated in colour on 57) comprise additional medallions of Constantius depicting the emperor raising the personified Britannia from her knees, whilst being crowned by the winged Victory. The PIETAS AUGG "legend emphasises the pious duty of the emperors in helping a beleaguered province". Mayer (2006) observes how both the medallion legend and a contemporary rhetor make no reference to civil war, but rather - at least in the poetical case - to victory over barbarians.

${ }^{43}$ Abdy (2006) 55, highlights the medallions as gifts to senior staff and how in the Beaurains hoard, the owner's promotion up the senior ranks is seemingly matched by a proportionate rise in the monies received. 
Heightened regular moneys and extras for the wider troop bodies across the 3rd-c. upheavals played a significant part in prompting the progressive debasement to extremes of silver coin issues - this was partly caused by civil conflict creating fragmented state control over metal resources, suppliers and mints. ${ }^{44}$ As a result, we also observe episodes of 'coin copying', whereby mints such as Trier and temporary military mints, as along the Danube, issued cast bronzes and false silver coin, presumably to counter short-term exigencies as official supplies ceased; striking are incidences of copying in Britain and Gaul in the A.D. $260-80$ period, and again in the 350 s. $^{45}$ Noticeably, it is only after the demise of the 'Gallic Empire' and the claimed restoration of empire that scope presented itself under Aurelian to seek to revive reasonable silver content, which might also then mean that 'Gallic' coins were discarded and hoards left unclaimed. ${ }^{46}$

Arguably, the internal Roman conflicts and crises of the 3rd c. are flagged by the coins, not just in terms of the often bewilderingly rapid change in emperors, names and faces-alongside the appearance of some usurper names, who never made it into general circulation through their rapid demise, and who, therefore, passed the bulk of the population by-but also on the imagery and legends of the issues of the later Empire. ${ }^{47}$ Legends — such as on the Arras Medallion noted aboverecalling (perhaps more in hope than in reality) 'restoration', 'renewal', 'peace', 'security' and 'piety' abound, framing images of supportive gods, trampled captives, walls and gates, or occasional warships (fig. 5). Words, ragged strikings of coins, and the struggling supply of these can only have added to the wider social tension which is sensed rather than seen in the archaeological record. As with the Arch of Constantine discussed above, the perception of the names, words and images, by elites and general public alike, cannot be traced, but the efforts of the emperors and moneyers to portray and name suggest an audience that did see and listen.

In the East, an emblematic example is provided by inscriptions and coin issues proclaiming new powers based at Palmyra. In Gallienus' reign, recognition of consular rank was awarded to one Odaenathus (Odeinath), a possible self-appointed governor, whose clan had perhaps only recently taken root in the city, but who provided Palmyra and distant Rome with victories-perhaps just localised affairs - against Persia, and in theory secured the eastern frontier; in local documents, Odaenathus also appears with the title of 'king of kings' in recognition of his achievements in safeguarding Palmyra and her lands. This label of authority was passed on to his son Vaballathus when Odaenathus was assassinated along with his elder son in A.D. 267-perhaps at the instigation of his wife Zenobia, who became effective regent over this junior son. Coins produced at Antioch and Alexandria in 271-72 comprise doubled-headed issues, with the new (western) Roman Emperor Aurelian on one side, and Vaballathus on the other, and with legends denoting the latter as rex, imperator and dux Romanorum (fig. 6a and 6b). Potentially these issues reflect a call for shared power at a time when Aurelian was still securing his own position in the West, and reflect a route to sanction or authorise Vaballathus and Zenobia at Palmyra. But, when Aurelian began forcibly to move eastwards against these perceived usurpers, new coins start to proclaim Vaballathus alone as

${ }^{44}$ Duncan-Jones (2004) 43-47 highlights such output as tied particularly to the need to provide largesse to the army, and with hoarding linked to Roman troop concentrations - 45, n.113. He argues thus that "the great thirdcentury debasement was not merely a result of heavier spending, but also indicates dwindling resources" with mining output — or wider access to the metals - dramatically hit.

45 King (1996) 239-41. Howgego (1996) meanwhile highlights how scrutiny of the issues in mid 3rd-c. hoards in these same areas testifies to a notable 'dislocation' between East and West Roman Empires. For an indepth study of the 3rd-c. coin hoards of Gaul and Germany, see Haupt (2001), recording over 1,700 hoards with end issues of between A.D. 180 and 280 - but note the review by Peter Guest in Britannia 36 (2005) 514-15.

${ }^{46}$ By then signs existed of a fair level of demonetisation in many parts of the Empire: thus Katsari (2005) charts changes and decay in silver and bronze issues (from hoards and excavated deposits) in 3rd-c. Asia Minor. She highlights the reign of Gallienus as the most unstable coin-wise, matching the far-flung politico-military vicissitudes. See also Katsari (2003) and her wider analysis of gold and silver, observing the limited visibility of gold coin in hoarding in the 3rd and 4th c., perhaps indicating that gold was viewed more as bullion than coin; nonetheless, the presence of gold coin over the frontiers is seen as merchant-linked rather than as tribute, with the latter best served by gold bars.

${ }^{47}$ Reece (1999a) 35-38 offers useful comment on portraiture on 3rd- and 4th-c. coins: "The third century, which has ... been called a desert of dated monuments, shows a quite remarkable free-for-all in coin portraits" with many a worried looking 3rd-c. emperor-except for the very 'tranquil' Gallienus; Reece identifies how Gallic Empire coins show high-quality portraiture overall. 
Augustus, thus counter-attacking Aurelian "ideologically by claiming imperial authority" —if not for long. ${ }^{48}$

Fig. 6a and b Billion antonianus of Vabalathus (268-72). $20 \mathrm{~mm}$, Mint: Antiochia 272.

Obv: IMP C AVRELIANVS AVG/H Radiate, draped, and cuirassed bearded bust of Aurelianus right. Rev: VABALATHVS V C R IM D R Laureated, draped bust of Vabalthus right.

Ref: Mattingly-Sydenham, RIC 5381 (Copyright image Andreas Pangerl, www.romancoins.info).

Discerning civil war propaganda in coin issues is a research area to be encouraged, to weigh up the value of legends and claims of GLORIA ROMANORUM, FEL TEMP REPARATIO, RESTITUTOR REIPUBLICAE, SPES ROMANORUM and SALUS PROVINCIARUM and REIPUBLICAE in their contemporary politico-military context in the 3rd to 5th c. Specific mint issues in divided rules, imagery before and after restorations, and coin qualities, are all routes of discussion. Two small examples might be Vetranio's 'illegal' coins, issued from Thessalonica and bearing the legends VIRTUS EXERCITUM and, more tellingly, CONCORDIA MILITUM; secondly, there is the series inscribed DOMINO NOSTRO, which is attributed to output from Carthage in the late 4th or early 5th c., probably during Gildo's or Count Boniface's revolts from the Italian government, when the issuer showed "evident reluctance... to inscribe a name or precise title on his coins". 49

Finally in this section, we might observe how some coins may have taken on symbolic roles in episodes of civil upheaval. Thus, Morelli discusses how in the 3rd c., there is a perceptible increase in the use of coins, often gold issues, as pendants on necklaces, either in multiples (such as in an example reconstructed for the Beaurains hoard, and featuring 8 coins of 2nd- to 3rd-c. date), or singly, and occasionally used as settings in rings. ${ }^{50}$ One pendant-coin is of Vittorinus, a usurper-successor to Postumus in the Gallic Empire in A.D. 268-70, found near Aja in the Low Countries; another is a rare Italian example (a majority of known finds coming from regions like Gaul, the Danubian provinces and Egypt) from Parma, featuring an aureus of Gallienus, whose deposition in a hoard may well have coincided with the assassination of Gallienus. In both instances, the use of gold, ornate border settings, and their display as pendants, can be viewed as signifying a desired visual impact, and a route to expressing a precise political leaning and loyalty - by both males and females (since the necklaces imply female owners).

\section{MEN (AND WOMEN)}

The constancy and the brutality of the conflicts of the 3rd c. must have impacted on a wide variety of levels which drastically damaged populations in a number of areas, mentally, physically and socially: through trauma and death - family members lost, raped, dispossessed; through economic hardshipfailures to gather in or have access to foodstuffs, with markets and supplies disrupted or commandeered, and lands not properly tended; and through reduced childbirth, as fear and food shortage impacted on the basics of living. As archaeology shows, frontier territories in many parts of the West show a reduced landscape, through a thinning out of farms and population. ${ }^{51}$ Although frontiers and towns and forts did persist once reactivated or restored, as around Trier, supplies and

\footnotetext{
${ }^{48}$ Long (1996). The creation of a fortress town (or at least a reinforcement and re-naming of an older site) of Zenobia (Halabija) on the Euphrates was perhaps part of a Palmyrene effort to secure control in Syria (as opposed to against Rome) in A.D. 270. Gerster and Wartke (2003) 159-65 provide some fine aerial views of the well-preserved site which saw Diocletianic renewal and then activity into the 6th c.

${ }^{49}$ Carson et al. (1978) 77, 58. Whitby (2004) 180 correctly observes how soldiers were the main audience for most of these coins.

${ }^{50}$ Morelli (2009), notably 89-93. Significantly, in many cases, the coins' settings in pendants appear to have been contemporary or near contemporary to their minting, suggestive of a particular or targeted output - might this equate with new style donatives to loyal staff or soldiers?

${ }^{51}$ Van Ossel and Ouzoulias (2000) and earlier work by Wightman (1981) for Trier; summarised in DuncanJones (2004) 32-33. Van Ossel and Ouzoulias show no single pattern prevailing, but with patches of loss. They do note, however, the numismatic and archaeological evidence for the Alf valley downstream of Trier, where fires and abandonment on some sites "can be linked to the events accompanying the usurpation of Magnentius and Decentius" (138). Wider comments and views on damage in the West in Witschel (2004).
} 
manpower now often came from further afield - from deeper within the provinces, but also with an increasing reliance on non-Roman troops drawn from over the frontiers to counter the internal voids. It is easy to over-dramatise this, and at the same time it is easy to contrast this by identifying a fairly busy and effective army in the Tetrarchic and Constantinian periods, but we should not in any way minimise the manpower drain created by both civil and external conflict in the two generations before, as indeed in the conflicts of A.D. 310-20.

Whitby noticeably identifies how the evidence of later 4th-c. laws may well reveal how very severe problems of recruitment are registered in the wake of the civil wars and suppressions of Magnus Maximus in A.D. 386 and Eugenius (in 394), with scared provincials damaged by the actions of two sides, with uncertainties of who to support, flights and loss of life. We can note, for example, Eutropius' claim in his overview of the clash between Constantius II and Magnentius at Mursa in 351 that 'great resources were used up in that battle, sufficient for any foreign wars which could have won many triumphs and brought peace'. ${ }^{52}$ Archaeologically, our problem lies in not being able to trace such losses, notably through burial evidence: as noted above, we have few tombstones that speak directly of the casualties in the many Roman civil wars, and there are even fewer known or excavated and published cemeteries in Italy, Gaul or elsewhere, that can be linked to communities affected by civil war-certainly, no mass war graves are known, and instances of unburied or brutal killings near frontier sites are linked more to barbarian raids. ${ }^{53}$

Military historians generally agree that Roman manpower losses and military demands were prompts for increased use of non-Roman forces, notably Goths, in the Roman armies from the later 4th c., and, in the context of the early 5th-c. West, events on the Rhine and the movements of the Goths in the Balkans and then Italy required that a reliance on non-Romans grew substantially-although this transition is still to be wholly recognised archaeologically along the frontiers and within provinces. As known, Italy's pull sees a weakening of military cover across Britain, Gaul and Raetia, all subsequently reflected in those provinces feeling forced to look to themselves and their own resources to ensure their survival, with new, more local centres of political gravity emerging within these provinces. New usurpers, local alliances with enemies, and the rise of what have been termed 'selfhelp' groups - seeking influential or wealthy leaders close at hand to guide and secure communitiesare documented internal responses to the upheavals of the first decades of the 5th c.; all might count as 'civil war' or 'uprisings'.

New physical reactions might be expected-city walls repaired, villas fortified, refuges created, open weapon display: whilst the archaeology cannot be tight enough, arguably, to pinpoint these and their politico-military contexts, nonetheless, we might question the existing data more, so as to consider whether there was less of an external or 'barbarian' threat than there was an internal one. One example to note is the later Roman (considered 4th-c. and pre-Visigothic) re-occupation or re-use of hilltop sites across sectors of the Duero plateau in the Burgos province of Spain, and proposed comparable refuges or upland seats in the area of the Roman town of Clunia; such movement of farming groups from plain (farm or villa) to hills represents local responses to insecurities, but we need note how some hillforts were selected in regions like western Britain as new elite power centres. $^{54}$

Such leaders and groups were also required in some regions to deal with other responses to state fracturing, such as elevated levels of rural banditry and urban dissensions. In terms of banditry, the law codes make clear that bouts of lawlessness, runaway slaves, army desertion, and the flight of

\footnotetext{
${ }^{52}$ Eutr. 10.12. Whitby (2004) 164-70; Lee (2007) 74-79. Elton (1996) 152-55 prefers to see no sizeable shortage of manpower.

${ }^{53}$ Urban cemeteries of later Roman date have been studied at Milan and Concordia (the latter the seat of an arms factory), but, perhaps unexpectedly, these lack indications of social episodes linked to war. Reece (1999b) reviews the publication of a cemetery of ca. 70 burials at Iutizzo Codroipo in Friuli, NE Italy, which the excavators, on the basis of belt fittings and coins, set to the mid 4th c. and, perhaps incautiously, they label the males as 'soldiers of Magnentius'; Reece accepts a change in rite in this older cemetery at this date, but queries whether these fittings imply newcomers and soldiers, or rather locals gaining a new employment and mode of display. More dramatic are the executed members of a Roman family on a farm at Harting in Bavaria-tortured, scalped and thrown into a well in ca. A.D. 260 and linked to Alamannic raids: Carroll (2001) 138.

${ }^{54}$ On northern Spain, see Cepas (2006) 205-206; for hill-fort re-use in the context of 5th-c. Britain, see White (2007) 165-76 and Faulkner (2000) 178-79. For Italy, Christie (1991) and (2006) 473-77 discusses how far some upland sites were natural movements, refuges (temporary or permanent), or had military roles.
} 
some urban refugees, fuelled groups of bandits, the best documented being the Bagaudae or Bacaudae, though this label was perhaps applied with a broad brush to any rebellious rabble when the State sought a crackdown on lawlessness. Whilst better documented in 5th-c. Gaul (Brittany notably) and northern Spain, reference to the what appear to be larger, organised groups of Bagaudae as rural or peasant militia or bandits, begin already in the later 3rd c. (for example, the Emperor Maximianus suppressed a horde in A.D. 289); they are identified in various ways, but generally in the context of a breakdown in official control, with displaced or dispossessed groups of peasants and slaves, overburdened by tax or other demands, seeking their own form of order, organised around chiefs and would-be generals.

Their equation in state texts with 'barbarians' is not dissimilar to imperial triumphal images and panegyrics denouncing usurpers and fellow Romans who work against legitimate rule and order. Their origins in essence lie with the traumas of the 3rd-c. crisis and civil wars, where state and nonstate demands and exactions, and plundering by rivals and by barbarian raiders, forced groups into such 'self-help' units. How many and how unified such groups were is wholly unclear, and there is currently no archaeology to trace them, although conceivably some of the burials in parts of late 4thand early 5th-c. Gaul with weaponry could be seen as belonging to estate militias and local leaderswho may or may not have been viewed centrally as Bagaudae, but who as landowners, may have been actively defending their properties as a matter of course in times of breakdown in normal order (civil war, Bagaudic raids, Gothic and Suevic attacks or threats from state officers, notably tax collectors and army recruitment gangs). ${ }^{55}$

\section{REPRISALS}

Acts of aggression were not just by soldiery against soldiery, but also by soldiery against civilians, whether in the context of troops being billeted in towns or on estates, and forcibly requisitioning space and supplies, tools, animals and, of course, women, or where troops move in to clear out and often kill supporters (and their families) of failed usurpers or dethroned emperors. Authorised acts of ransacking and polluting properties as 'pay-back', or unauthorised acts by soldiers of theft, damage and rape against others, cannot be identified without text, graffiti or clear evidence of destruction and/or levelling of properties. ${ }^{56}$ More often, a property might be confiscated (and its owners either killed or made slaves) and given to a new owner as a reward for their service to the Empire. Some such events may have nothing to do with the military, but may be locals exploiting upheavals during, or in the aftermath, of civil conflict, and seeking to improve their own lot at the cost of others.

The earlier archaeological efforts to tie in destructions, fires, bodies and abandonment of Roman villas and farms in south-western England to Ammianus Marcellinus' tales of woe in the 'Barbarian Conspiracy' of A.D. 367-sites such as Keynsham with its main rooms fired and at least one body left in collapsed wall debris, and Nuthills, with claims of the villa having been "mercilessly raided" - in reality struggle to fit a tight chronology; yet their general association with the mid- to later-4th c. can as easily be tied into local and regional raids, civilian conflicts, slave and brigand attacks. Clearances and renewals at sites like Brislington may denote new owners, or the displaced former owners coming back once events had settled down. ${ }^{57}$ In the case of Gadebridge Park (Herefordshire), demolition in the mid 350s has been linked to a rooting-out of supporters of the defeated Magnentius under Constantius II, whose agent Paul the 'Chain' took vicious exaction on the

\footnotetext{
55 Although landowners, by opposing state officials may have then been classed as Bagaudae; Drinkwater stresses a lack of continuity between the 3rd- and 5th-c. entities: Knight (1999) 54-56; Drinkwater (2007) 180-81 and (1992). On the burial evidence, see Halsall (1992). Ward-Perkins (2005) 54 observes how the settlement of 'allied' Visigoths in A.D. 419 in south-west Gaul was partly designed to counter the revolt and movements of Bagaudae there. Faulkner (2000) 176-77 ponders peasant revolt parallels in early 5th-c. Britain, but Snyder (1998) 227-28 sees no Bagaudae here.

56 See the detailed comments by Lee (2007) in his ch.5 'The Experience of War'. Elton (1996) 196-98 comments on the fate of usurpers and their supporters, arguing that "persecution of a rebelling or usurping faction was rarely carried out beyond its upper ranks, probably because it was counter-productive", though regiments might be disbanded and re-assigned-see note 57 below on troops in Tripolitania.

${ }^{57}$ Branigan (1976) 136-40.
} 
usurper's weakened homeland - 'descending like a sudden torrent upon the persons and estates of many people, [he] spread ruin and destruction in various forms'.58

The case of Palmyra can again be mentioned. Aurelian's vicious exactions against the city of Zenobia are suitably documented and, if only in part, traced archaeologically, and by the Tetrarchic period a new, reduced city, part military, had been imposed on the west flank. The old city spaces saw some continuity, however, although there is a likely significant change imposed here too: the palace and power centre of Odaenathus and Zenobia had been sited in the centre of the city, along the Great Colonnaded Street, and between the sanctuaries of Nabu, Balashamin and Bel, close to the agora; the street and tetrastyle were the focus for statues and dedications by the local princes and elite. Whilst little is known of the palace, it has been argued that, as an additional act of cancelling out Zenobian power politics, the site was replaced by the Baths of Diocletian, active already by A.D. 284, and thus probably begun soon after Aurelian's actions. ${ }^{59}$ Otherwise, in fact, the religious structures were little affected, the only exception being the sanctuary of the warrior goddess Allat, where statuary appears to have been bashed about and decapitated, with these materials re-used in a re-built precinct wall of $c a$. A.D. 300 - such damage to statuary might well have been by eager Aurelianic troops, who may well have despoiled the sanctuary of portable wealth too. ${ }^{60}$

Civilians could suffer the consequences of their city councils favouring or siding with usurpers and rebels - even if, of course, such siding may have been the decision of just a few individuals, with the urban communities either ignorant of the rebellion, or the imperial struggles being enacted elsewhere. Thus we are informed of the brutal retributions authorised by Maximinus via his legate Capellianus, following the unsuccessful revolt of the Gordians (I and II) in North Africa, put down after just three weeks in A.D. 238, and resulting in their execution in Carthage-only for a third Gordian to gain more lawful (of a sort) accession to the throne, also in 238. Archaeological traces of destruction of houses and damage to public units, such as the amphitheatre at Thydrus (El Jem/El Djem), have been attributed to the reprisals by Capellianus, whilst the massive refurbishment of the amphitheatre there is seen as an act of compensatory munificence and renewal by Gordian III (perhaps also completing work started by Gordian I/II) — the association is tempting, although the dating awaits corroboration. ${ }^{61}$

The image and value of the emperor were, I would argue, seriously diluted across the $3 \mathrm{rd}$ c.: not only did citizenry in town and country lose track - except by coin and legend - of the rise and fall of emperors, pretenders, usurpers and generals (unless forcefully informed of a new name in power by passing soldiery, tax collectors or deserters), but the claim that these emperors were genuinely worthy of worship must have sounded very hollow. A consequence might well have been the demise of many an imperial cult shrine and centre in the West especially, and, perhaps, attacks on shrines favoured by individual rulers or usurpers. Charting the demise of imperial cult sites is not an easy task, as too few have either been recognised or excavated to sufficient degree or quality to identify sequences of decay; there is a temptation also to assume that where destruction or loss occurs then it relates chiefly to a

\footnotetext{
${ }^{58}$ Amm. Marc. 14.5-Paul continued his dirty (but presumably sanctioned) deeds against supporters of the tyrants Gallus (15.3) and Silvanus (15.6). Gadebridge: Neal (1974). The novel by Vansittart (1983) to my mind provides a very useful recreation of some of the mixed-up socio-political events of the second half of the 4th c. in Britain from the perspective of a would-be lead player, who in reality has little scope to make any mark in the military confusion.

59 Yon (2001) 180. Stunning air photographs of the site, including the so-called Diocletianic Camp, are presented in Gerster and Wartke (2003) 117-30, nb. pl. 138, with the fortress-town of Halabija-Zenobia depicted on pp. 159-65. A lively history of Queen Zenobia comes in General Tlass (1986).

${ }^{60}$ Sauer (2003) 49-52 describes the Allat material, but hesitates in ascribing this closely to the emperor's reprisals; in contrast he more readily attributes the damage to the goddess' statuary in later 4th-c. events to Christians: "The contrast between the at most half-hearted pagan iconoclasm even in a city responsible for repeated rebellion and what was to follow over a century later is striking. One cannot help thinking that Aurelian and his troops felt more fear or respect for the pantheon of the defeated city than hatred for their enemies" -52 .

${ }^{61}$ Bomgardner (1981), citing Herodian 7.9,10-11. Bomgardner argues that the amphitheatre was even then not completed after Gordian III's 5 year reign, since the new emperor, Phillip, duly shifted his imperial focus to founding a new city at his own birthplace. Gordian III, meanwhile, took out his own anger on the legio III Augusta, which had helped put down the revolt of his father and grandfather: Mattingly (1995) 55 and 83 , observing how in Tripolitania some traces exist of possible absorption of disbanded legionaries into auxiliary or other detachments.
} 
change in state religion - i.e. the rise of Christianity - or to barbarian assault, rather than considering an altered mentality of locals and Romans. Thus, the recent archaeological analyses of the provincial cult centre at Tarragona in Spain, and of the imperial cult temples at Narona in Dalmatia and Eretria in Greece, have emphasised Christian iconoclasm as the lead player. ${ }^{62}$ For Narona, excavations in 199596 identified the well-preserved Augusteum, whose interior had remained largely intact since destruction in the 4th c.: here were recovered, in situ, a series of at least 14 life-size and three lesser cult statues of good quality carving of the 1 st and 2nd c., all toppled and all decapitated, with some of the heads wholly removed, and others discarded outside or cast down the forum steps. ${ }^{63}$ The last statues belong to the 2nd c., but there is nothing to indicate any dedications of new works in the 3rd c. However, destruction of the statues and a deliberate in-filling of the building are set by the archaeologists only to the end of the 4th c. "suddenly and violently, probably following Theodosius' Edict" ${ }^{64}$

A comparable scenario is proferred for Eretria, in the sense of the presence in destruction deposits of the 4th c. of statuary belonging to 7 figures, mainly cuirassed emperors of the first two centuries A.D., but with one base at least belonging to $c a$. A.D. 200, and a nearby statue base of Caracalla attested. It is argued that the coins from the destruction layer-which included debris from the statuary, which was smashed into small fragments and the heads destroyed-show the temple's demise after the 350s: "We seem therefore not to be dealing with a typical damnatio memoriae of one or more emperors; the destruction of heads and hands and the cutting of all the sculptures into minute pieces is more typical of Christian iconoclasm". ${ }^{65}$

Tarragona's case differs in part due to its role as provincial capital and seat of the provincial cult and council, and here, the scale of operations for the imperial cult was on a grand scale, with massive redevelopment coming under Vespasian, when the upper town there was conceived as the grandiose stage for the seat of both council and imperial cult - the latter with a precinct containing the temple to Rome and Augustus, the former occupying a lower terrace and featuring statues dedicated to and by the priesthood of the cult. ${ }^{66}$ The city's high status ensured a constancy of elite benefactions, enabling construction of various public monuments, and competition for the honour of the priesthood. The picture is much changed by the mid 3rd c., by which time the priesthood statuary had come to an end, and urban activity as a whole was reduced (including the demise of the theatre); where new work occurs, such as restorations to the amphitheatre, or the setting up of honorary statues to the emperors in the 4th c. (some of their pedestals were actually re-cut from earlier ones), the effort comes from state officials or government grants, implying a removal of elite participation at Tarragona, and suggesting more widely a loss of confidence in state and cult. Although not an immediate reaction to civil war, the impact of warfare on society, economy and the status of the emperor are borne out in the data here and at Narona and Eretria. What we cannot glean at the latter sites, however, is how far imperial cult sites were ignored or even attacked by ordinary people in the wake of civil wars and usurpations; in moments of social upheaval, conflict can spill out on many levels, few of which can be traced archaeologically_notably the persecution of religious groups (see below).

Much is owed to Eberhard Sauer's provocative book (2003) which prompts us to look in a new way at Roman temple art and its survivals and fates, as he identifies strongly the contexts and modes of iconoclastic damage (defacing, smashing, decapitation, etc. of statues, murals, etc.). His over-riding intention is to highlight religious hatred and exactions against an enemy, and a recurrent theme is Christian acts against pagan cult images in the Late Roman period, which he examines to

\footnotetext{
${ }^{62}$ Tarragona: Keay (1996). Narona: Marin (2001). Eretria: Schmid (2001). On the imperial cult in general in the West, see Fishwick (1992) and (2002).

${ }^{63}$ Marin (2001) 97-111 on identification of the statues, which include Augustus, Livia, Tiberius and Vespasian; three of the heads were recovered from the forum in 1874 and 1878. The lack of a statue of Nero could be seen as a damnatio memoriae (103). One might note, from Fishwick's study, how many imperial cult sites see a busy investment under Vespasian from A.D. 70, following the destabilising civil war of 69, in part to secure his own footing at the start of a new dynasty: he modified the whole cult to centre on Roma, on the deified dead and on the living emperor - the latter as a link between present and past; a fuller, more formalised priesthood was instituted too, and there is encouragement to municipal cult centres: Fishwick (2002) 223-26.

${ }^{64}$ Marin (2001) 91-92.

${ }^{65}$ Schmid (2001) 140-41.

${ }^{66}$ Keay (1996) nb. 28, 33, 36.
} 
good effect, especially in the context of the destruction of Mithraic sites and cult works. ${ }^{67}$ But, as seen, we ought not to ignore defacings and destructions much prior to these Christian acts of violence: damnationes memoriae are known, forming official deletions of names, faces, records of rulers and, occasionally, of lessers, but these effectively acted as a guide to individuals, whether governors, tribunes, bakers or slaves, in terms of how perceived evils and wrongdoers could be cancelled out. ${ }^{68}$ Episodes of ransacking, raiding, looting by soldiers and thieves or by ordinary folk in the context of civil war must have been frequent - as statements of new authority, rejections of others, or simply as opportunities for gain.

Sauer overall sees the destructors as either barbarian raiders/occupiers or Christians. In discussing episodes of statue smashing in parts of the old Roman frontier province of Germany in town, sanctuary or villa contexts (e.g. Ladenburg, Dieburg and Bad Wimpfen), Sauer prefers to await the Alemannic take-over after A.D. 260 as the context, or to suggest earlier raids. He may well be correct, but in the case of the desecration (twice) of a Jupiter column at Ladenburg (a Roman town near modern Heidelberg), where, some time in the 3rd c., the Jupiter sculpture and other materials were thrown down a well, only then for the column to have been restored before a second dumping of a demolished and fire-damaged monument took place some time later, alternative views can be proferred. ${ }^{69}$ Sauer's argument is that the giant Jupiter columns - about 13 existed in this one townwere highly visible symbols of Roman imperialism, which provoked reaction from invaders, and were a natural focus of aggression; yet surely we cannot exclude local reaction against Rome and the State in the context of 3rd-c. civil war and the town's neglect by official arms, and local frustration meted out on the monument to Roman security? Similarly, while the excavators of the imperial cult buildings at Narona and Eretria may well be perfectly correct in pinpointing desecration and destruction as sanctioned actions by Christians following imperial legislation, we do not know if these were acts by soldiers, monks, the local bishop, clergy and slaves, disgruntled citizens, or a mix of idealised churchmen and a suitably energetic group of locals, who enjoyed completing the looting that had gone before, and who might have hoped for possible booty from the exercise.

Christians play a different role of course in the 3rd-c. upheavals and in the re-affirmation of the State under the Tetrarchs by being singled out for persecution in both military and civilian contexts: aggressive persecutions in the mid-3rd c. under Decius and Valerian can be perceived as efforts to require loyalties to the struggling authorities in periods of insecurity, inside and without the Empire, and can also be perceived as distrusts within communities as stresses took hold; renewed persecution under Galerius (and Diocletian) at the start of the 4th c. was aimed at reinforcing the new image of emperors favoured by specific gods (notably Jove and Hercules). Coin images, dedications and the re-naming of army units and even a few towns (such as Gorsium-Herculia in Pannonia) stress this Tetrarchic approach, although we have little to show a renewal of display inside imperial cult centres, bar the chamber and its wall paintings in a converted part of the Temple of Ammon at Luxor, Egypt, attached to the Diocletianic fort; potentially more emphasis was made on display outside, in public spaces and basilicas, through statuary, often of colossal dimensions (as, for example, Maxentius' Basilica Nova in Rome). ${ }^{70}$

\section{CONCLUSION: CIVIL CONFLICT PRESENT AND PAST}

\footnotetext{
${ }^{67}$ Sauer (2003) - especially 79-88 on Mithraic cult images, and 131-56 on this and other oriental cults. Damage, mutilation or annihilation of faces and heads of statues and relief sculpture stand out-e.g. at the sanctuary at Sarsina with its cult statues of Isis, Cybele and Serapis brutally battered and scattered (139).

${ }^{68}$ See Rambaldi (2009) 139 with catalogue entries 1-2 for examples of 3rd-c. anarchy period erasures of names of emperors from temple and other inscriptions, such as those of Philip the Arab and of Gallienus, at the temples of Jove and Serapis, respectively, at Abitina (Chouhoud el Bātin) in Africa Proconsularis.

${ }^{69}$ Sauer (2003) 55-57. Carroll (2001) 138, noting traces of destructions by raids, also points out how "The possibility that signs of violence in the third and fourth centuries could have been the result of Roman armies engaged in civil wars, however, is rarely considered" - e.g. feuding emperors inviting in German groups such as the Iuthungi and Alamanni, as seems to have occurred between Postumus and Gallienus.

70 Janes (2002) 48-50 on the persecutions; Elsner (1995) 173-76 on the imagery at Luxor. See Lee (2007) 193-98 on soldiers and persecutions as also on their role in destroying pagan shrines later. On evidence for Christian soldiery pre-Constantine, see Lee (2007) 176-82.
} 
Modern parallels of civil war and their consequences, in African states in particular, show frenzied gangs at work, despoiling and looting, setting cars on fire, hurling stones, controlling streets armed with makeshift weapons, with minimal guidance, and with the 'authorities' overseeing through hardhand violence, and through hard-men bodyguards; how often the individuals concerned are fighting for a specific cause, or are simply caught up in the turmoil or even excitement, is never clear. Whilst mention could be made of the civil war genocide impacts in Sudan, or in Rwanda in 1994, when the Hutu government's murderous efforts to exterminate the rival Tutsi population saw the massive loss of life and the brutality of the Hutus, a recent event indicative of the upheaval and confusion caused through civil violence, was the election in Kenya at the end of 2007, marked by claims of the rigging of votes and counting, followed by riots and tribal conflict; if never spilling into the ethnic brutalities of the Rwandan Hutu, by 19 January 2008, the death toll was set at 800 (including 30 burnt alive in a church) on 1 January, and with a claimed 250,000 displaced refugees. ${ }^{71}$ And the most recent upheavals (2011-12) in Egypt and Syria especially have done plenty to flag to us the potential impact of mob activity, ailing governmental responses, and resultant societal and urban breakdowns. The 'official' noises and words from the Syrian President and his army were smokescreens to violence meted out against opposition activists and civilians alike, and with the tension and damage dragged out despite vague outside threats and denouncements. ${ }^{72}$

The looting by locals of shops, hospitals, state buildings and museums in the Iraq invasion by the US was not something sanctioned by the incoming forces, but happened through the convenience and opportunities that confusion and upheaval and a loss of normal authority brought; here, the toppling of the monumental statues of Saddam Hussein were largely organised televised events, attracting onlookers and contributors, with groups keen to side with the new powers. ${ }^{73}$ The struggle for cohesion and order since, and the emergence of factions in particular, perhaps parallel some of the events felt in civil conflict in later Roman times. Much of the hurt and violence of the warfare is human and psychological; and whilst bombs and tanks have meant that an archaeology of modern Iraq would identify clearly the warfare, and whilst the civil strife is known and reported, the latter may leave minimal trace - although the evidence of executions and 'ethnic cleansing' under Saddam Hussein now made evident from uncovered mass burial pits, as likewise excavated to show the conflicts in Bosnia and Spain, can yield a horrific graphic depiction of the results of such wars.

A final point of comparison might be drawn with the events centred around Chechnya and Russia, with the former resembling a breakaway Roman province in the late Empire as centralised control deteriorates: after the Soviet Union collapsed in 1991, Chechnya first ran as a republic within the Russian Federation, and then drove for independence, a move fiercely opposed by Russia: major military aggression by the latter across 1994-96, separatist reprisals, persistent diplomatic exchanges and breakdowns, economic hardships, and ongoing distrust, all ring loud as parallels with the discussions above. ${ }^{74}$

In our sketched 3rd- to 5th-c. Roman contexts, there are, as has already been seen, archaeological, iconographic and other indicators, which can point to conflict, propaganda, loss and response; destruction deposits and walls, however, remain too frequently tied to the non-Roman enemies, and we perhaps underplay how much in reality reflects the civil wars, which were as, if not at times, much more brutal and more debilitating than the barbarian assaults prior to the 5 th $\mathrm{c}$. What we should at least recognise is that military changes - defence (urban and military) as well as army composition and tactics - in the Late Empire, were responses to upheavals wrought by both internal and external threats; the architectural redefinition of towns especially links to an insecurity which prompted the uncertainties of internal Roman stability. Civil wars were powerful and debilitating

${ }^{71}$ The Independent, 29.1.2008 (issue no.6642), articles by Steve Bloomfield and Richard Dowden, with the emotive headline: 'They killed our people, so now we will do likewise. We are just revenging'. Acts of violence extended even against tourists, reporters and hospitals.

${ }^{72}$ Besides numerous and ongoing newspaper, television and other press coverage, see also outline summary of the Syrian uprisings at: http://en.wikipedia.org/wiki/Syrian_uprising_(2011\%E2\%80\%93present) noting a potential loss of life in the order of 30-50,000 [accessed 2.11.12].

${ }^{73}$ The Independent, 10.4.2008 (issue no.6704, Extra), Picture Post: The Fall of Saddam - and the 'Green Blob', article by Kim Sengupta, reports on the derided replacement sculpture called officially 'Survivor', but locally known as 'The Green Blob'.

${ }^{74}$ Rapid guide to 'Crisis in Chechnya' is presented in http://www.globalissues.org/Geopolitics/Chechnya [accessed 23.5.08] 
realities under Rome: recognising the potential of observing the impact of civil war from other sources - coins, burials, cult desecration and so on - is important, although as yet far too few secure data exist to work with.

\section{ACKNOWLEDGMENTS}

My thanks go especially to Andrew Merrills (Leicester) and Stanley Ireland (Warwick) for their helpful suggestions, corrections, etc. in modifying and tightening up this paper, and to the two anonymous referees for additional guidance. And final thanks go to Andreas Pangerl for kindly supplying figs. 6a, b.

\section{BIBLIOGRAPHY}

\section{Primary Sources}

Amm. Marc. $=$ Rolfe J. C. (1963) ed. and trans. Res Gestae (London 1963).

$C I L=$ Reimerum G. (1862) ed. Corpus Inscriptionum Latinarum (Berlin 1862).

Eutr. = Santini S. (1979) ed. Eutropii Breviarium ab urbe condita (Leipzig 1979); Bird H. W. (1993) trans. The Breviarium ab urbe condita of Eutropius, the Right Honourable Secretary of State for General Petitions: dedicated to Lord Valen, Gothicus Maximus and Perpetual Emperor (Translated Texts for Historians 14) (Liverpool 1993).

Herodian = Stavenhagen K. (1967) ed. Herodian, ab exessu divi Marci libri octo (Stuttgart 1967).

$I L S=$ Dessau H. (1856-1931) Inscriptiones latinae selectae (Berlin 1856-1931).

Mattingly-Sydenham RIC 5 = Webb P. H., Mattingly H. and Sydenham E. A. (1968) The Roman Imperial Coinage, volume 5, part 2: Probus to Diocletian (London 1968).

Pan. Lat. = Mynors R. A. B. (1964) ed. XII Panegyrici Latini (Oxford 1964); Nixon C. E. V. and Rodgers B. S. (1994) trans. In Praise of Later Roman Emperors: the Panegyrici Latini (Berkeley 1994).

SHA = Magie D. (1953) ed. and trans. The Scriptores Historiae Augustae (London 1953).

Veg. Mil. = Reeve M. D. (2004) ed. Epitoma rei militaris (Oxford 2006); Milner N. P. (1996) trans. Epitome of Military Science (Liverpool, 2nd ed. 1996).

Secondary Works

Abdy R. (2006) "In the pay of the emperor: coins from the Beaurains (Arras) treasure", in Constantine the Great: York's Roman Emperor, edd. E. Hartley, J. Hawkes, M. Henig and F. Mee (York 2006) 52-58.

Bakker L. (1993) "Raetien unter Postumus - das Siegesdenkmal einer Juthungenschlacht im Jahre $260 \mathrm{n}$. Chr. aus Augsburg", Germania 71 (1993) 369-86.

Beard M. (2007) The Roman Triumph (London and Cambridge, Mass. 2007).

Bishop M. C. and Coulston J. C. N. (1993) Roman Military Equipment from the Punic Wars to the Fall of Rome (London 1993).

Blockley R. C. (1998) "Warfare and diplomacy", in The Cambridge Ancient History, Volume 13: the Late Empire, A.D. 337-425, edd. A. Cameron and P. Garnsey (Cambridge and New York 1998) 411-36.

Bomgardner D. L. (1981) "The revolt of the Gordians and the amphitheatre at Thysdrus (El Djem)", in The Roman West in the Third Century: Contributions from Archaeology and History, edd. A. King and M. Henig (Oxford 1981) 211-14.

Bowes K. and Kulikowski M. (2005) edd. Hispania in Late Antiquity: Current Perspectives (The Medieval and Early Modern Iberian World 24) (Leiden and Boston 2005).

Branigan K. (1976) "Villa settlement in the West Country", in The Roman West Country: Classical Culture and Celtic Society, edd. K. Branigan and P. J. Fowler (Newton Abbot 1976) 120-41.

Buora M. (2002) ed. Miles Romanus, Dal Po al Danubio nel Tardoantico: Atti del Convegno Internazionale, Pordenone-Concordia Sagittaria 17-19 Marzo 2000 (Pordenone 2002).

Burgess P. W. (1992) "From Gallia Romana to Gallia Gothica: the view from Spain", in Fifth-Century Gaul: a Crisis of Identity?, edd. J. F. Drinkwater and H. Elton (Cambridge 1992) 19-27.

Cameron A. (2006) "Constantius and Constantine: an exercise in publicity", in Constantine the Great: York's Roman Emperor, edd. E. Hartley, J. Hawkes, M. Henig and F. Mee (York 2006) 18-30.

Cameron A. and Garnsey P. (1998) edd. The Cambridge Ancient History. Volume 13: the Late Empire, A.D. 337-425 (Cambridge and New York 1998).

Carroll M. (2001) Romans, Celts and Germans: the German Provinces of Rome (Stroud 2001). 
Carroll-Spillecke M. (1997) "The late Roman frontier fort Divitia in Cologne-Deutz and its garrisons", in Roman Frontier Studies 1995: Proceedings of the XVIth International Congress of Roman Frontier Studies, edd. A. Groenman van Waateringe, B. L. van Beck, W. J. H. Willems and S. L. Wynia (Oxford 1997) 143-50.

Carson R. A. G., Hill P. V. and Kent J. P. C. (1978) Late Roman Bronze Coinage A.D. 324-498, Parts I and II (London 1978).

Cepas A. (2006) "The ending of the Roman city: the case of Clunia in the northern plateau of Spain", in People and Space in the Middle Ages, 300-1300, edd. W. Davies, G. Halsall and A. Reynolds (Turnhout 2006) 187207.

Christie N. (1991) “The Alps as a frontier, AD 168-774', JRA 4 (1991) 410-30.

(1997) "Defences and defenders in Late Roman South-West Gaul”, JRA 10 (1997) 489-94.

(2006) From Constantine to Charlemagne: an Archaeology of Italy, AD 300-800 (Aldershot 2006).

Claridge A. (1998) Rome: an Oxford Archaeological Guide (Oxford and New York 1998).

Coarelli F. (1999) “L'edilizia pubblica a Roma in età tetrachica”, in The Transformations of Vrbs Roma in Late Antiquity, ed. W. V. Harris (Portsmouth, RI 1999) 23-33.

Corney M. (1997) "The origins and development of the 'small town' of Cunetio, Mildenhall, Wiltshire", Britannia 28 (1997) 337-50.

Donati A. and Gentili G. (2005) edd. Costantino il Grande: La civiltà antica al bivio tra Occidente e Oriente (Milan 2005).

Drinkwater J. F. (1987) The Gallic Empire: Separatism and Continuity in the North-Western Provinces of the Roman Empire, A.D. 260-274 (New York 1987).

(1992) "The Bacaudae of fifth-century Gaul”, in Fifth-Century Gaul: a Crisis of Identity?, edd. J. F. Drinkwater and H. Elton (Cambridge 1992) 208-17.

-- (1996) "The 'Germanic threat on the Rhine frontier': a Romano-Gallic artefact?", in Shifting Frontiers in Late Antiquity, edd. R.W. Mathisen and H.S. Sivan (Aldershot 1996) 31-44.

(2007) The Alamanni and Rome, 213-496 (Caracalla to Clovis) (Oxford 2007).

Duncan-Jones R. (2004) "Economic change and the transition to Late Antiquity", in Approaching Late Antiquity: the Transformation from Early to Late Empire, edd. S. Swain and M. Edwards (Oxford 2004) 2052.

Elsner J. (1995) Art and the Roman Viewer: the Transformation of Art from the Pagan World to Christianity (Cambridge and New York 1995).

(2000) "From the culture of spolia to the cult of relics: the Arch of Constantine and the genesis of late antique forms", PBSR 68 (2000) 149-78.

Elton H. (1992) "Defence in fifth-century Gaul”, in Fifth-Century Gaul: A Crisis of Identity?, edd. J. Drinkwater and H. Elton (Cambridge 1992) 167-76.

-------- (1996) Warfare in Roman Europe AD 350-425 (Oxford 1996).

Faulkner N. (2000) The Decline and Fall of Roman Britain (Stroud 2000).

Fernández-Ochoa C. and Morillo Á. (2005) "Walls in the urban landscape of late Roman Spain: defense and imperial strategy", in Hispania in Late Antiquity: Current Perspectives, edd. K. Bowes and M. Kulikowski (Leiden and Boston 2005) 299-340.

Ferrill A. (1986) The Fall of the Roman Empire: the Military Explanation (London 1986).

Fishwick D. (1992) The Roman Imperial Cult in the West (London 1992).

(2002) The Imperial Cult in the Latin West: Studies in the Ruler Cult of the Western Provinces of the Roman Empire, volume III: Provincial Cult, Part 1: Institution and Evolution (Religions in the GraecoRoman World 145) (Leiden, Boston and Köln 2002).

Galinié H. (2007) ed. Tours antique et medieval: Lieux de vie, temps de la ville (Tours 2007).

Gerster G. and Wartke R-B. (2003) Flugbilder aus Syrien: Von der Antike bis zum Moderne (Mainz am Rhein 2003).

Greenhalgh P. A. L. (1975) The Year of the Four Emperors (London 1975).

Halsall G. (1992) "The origins of the Reihengräberzivilisation: forty years on", in Fifth-Century Gaul: a Crisis of Identity?, edd. J. Drinkwater and H. Elton (Cambridge 1992) 196-207.

Haupt P. (2001) Römische Münzhorte des 3.Jhs. in Gallien und den germanischen Provinzen (Provinzialrömische Studien 1) (Grunbach 2001).

Hobley B. (1983) "Roman urban defences: a review of research in Britain", in Roman Urban Defences in the West, edd. J. Maloney and B. Hobley (CBA Research Report 51) (London 1983) 78-84.

Howgego C. (1996) "The circulation of silver coins, models of the Roman economy, and crisis in the third century A.D.: some numismatic evidence", in Coin Finds and Coin Use in the Roman World: the Thirteenth Oxford Symposium on Coinage and Monetary History, 25-27.3.1993: a NATO advanced research workshop, edd. C. King and D. G. Wigy (Berlin 1996) 219-36.

Janes D. (2002) Romans and Christians (Stroud 2002). 
Jobst W. (2002) "La Porta dei Pagani di Carnuntum e il limes danubiano pannonico nel IV secolo d.C.", in Roma sul Danubio: Da Aquileia a Carnuntum lungo la via dell'ambra, edd. M. Buora and W. Jobst (Rome 2002) 165-71.

Johnson S. (1979) The Roman Forts of the Saxon Shore (London 1979). - (1983) Later Roman Fortifications (London 1983).

Jones A. H. M. (1980) Augustus (London 1980).

Katsari C. (2003) "Bimetallism and the circulation of gold coins during the third and the fourth centuries AD", Münstersche Beiträge zur antiken Handelsgeschichte 22.1 (2003) 48-68.

(2005) "The monetization of Roman Asia Minor in the third century AD", in Patterns in the Economy of Roman Asia Minor, edd. S. Mitchell, C. Katsari and D. Braund (Swansea 2005) 261-88.

Keay S. (1996) "Tarraco in Late Antiquity", in Towns in Transition: Urban Evolution in Late Antiquity and the Early Middle Ages, edd. N. Christie and S. T. Loseby (Aldershot 1996) 18-44.

King A. and Henig M. (1981) edd. The Roman West in the Third Century: Contributions from Archaeology and History (BAR International Series 9) (Oxford 1981).

King C. E. (1981) "The circulation of coin in the western provinces, A.D. 260-295", in The Roman West in the Third Century: Contributions from Archaeology and History, edd. A. King and M. Henig (BAR International Series 9) (Oxford 1981) 89-106.

(1992) "Roman, local, and barbarian coinages in fifth-century Gaul", in Fifth-Century Gaul: a Crisis of Identity?, edd. J. F. Drinkwater and H. Elton (Cambridge 1992) 184-95.

(1996) "Roman copies", in Coin Finds and Coin Use in the Roman World: the Thirteenth Oxford Symposium on Coinage and Monetary History, 25-27.3.1993: a NATO advanced workshop, edd. C. King and D. G. Wigy (Berlin 1996) 237-63.

Knight C. (1845) Old England: a Pictorial Museum (London 1845).

Knight J. (1999) The End of Antiquity: Archaeology, Society and Religion AD 235-700 (Stroud 1999).

Kulikowski M. (2007) Rome's Gothic Wars from the Third Century to Alaric (Cambridge and New York 2007).

Leach J. (1978) Pompey the Great (London 1978).

Lee A. D. (2007) War in Late Antiquity: a Social History (Oxford 2007).

Liebeschuetz J. H. W. G. (1991) Barbarians and Bishops: Army, Church and State in the Age of Arcadius and Chrysostom (Oxford 1991).

Liverani P. (2005) "Il Arco di Costantino", in Costantino in Grande: La civiltà antica al bivio tra Occidente e Oriente, edd. A. Donati and G. Gentili (Milan 2005) 64-69.

Long J. (1996) "Two sides of a coin: Aurelian, Vaballathus, and eastern frontiers in the early 270s", in Shifting Frontiers in Late Antiquity, edd. R. W. Mathisen and H. S. Sivan (Aldershot 1996) 59-71.

Lyon J. (2007) Within these Walls: Roman and Medieval Defences north of Newgate at the Merrill Lynch Financial Centre, City of London (MOLAS Monograph 33) (London 2007).

Maloney J. (1983) "Recent work on London's defences", in Roman Urban Defences in the West, edd. J. Maloney and B. Hobley (CBA Research Report 51) (London 1983) 96-117.

Maloney J. and Hobley B. (1983) edd. Roman Urban Defences in the West (CBA Research Report No.51) (London 1983).

Marin E. (2001) "The temple of the imperial cult (Augusteum) at Narona and its statues: interim report", JRA 14 (2001) 81-112.

Mattingly D. J. (1995) Tripolitania (London 1995).

(2006) An Imperial Possession: Britain in the Roman Empire (London 2006).

Mayer E. (2006) "Civil war and public dissent: the state monuments of the decentralised Roman empire", in Social and Political Life in Late Antiquity, edd. W. Bowden, A. Gutteridge and C. Machado (Late Antique Archaeology 3.1) (Leiden 2006) 141-55.

Merrills A. (2010) “The secret of my succession': dynasty and crisis in Vandal North Africa”, Early Medieval Europe 18.2 (2010) 135-59.

Mertens J. (1983) "Urban wall-circuits in Gallia Belgica in the Roman period", in Roman Urban Defences in the West, edd. J. Maloney and B. Hobley (CBA Research Report No.51) (London 1983) 52-57.

Mitchell S. (2006) A History of the Later Roman Empire, AD 284-641: the Transformation of the Ancient World (Oxford 2007).

Morelli A. L. (2009) "Il gioiello monetale in età romana", in Oreficeria antica e medieval: Tecniche, produzione, società, edd. I. Baldini Lippolis and M. T. Guaitoli (Ornamenta 1) (Bologna 2009) 79-101.

Morgan G. (2007) 69 AD: the Year of Four Emperors (Oxford 2007).

Muhlberger S. (1992) "Looking back from mid-century: the Gallic Chronicler of 452 and the crisis of Honorius' reign", in Fifth-Century Gaul: a Crisis of Identity?, edd. J. F. Drinkwater and H. Elton (Cambridge 1992) 28-37.

Neal D. S. (1974) The Excavation of the Roman Villa in Gadebridge Park, Hemel Hempstead 1963-8 (London 1974).

Nixon A. and Rodgers B. (1994) In Praise of Later Roman Emperors: the Panegyrici Latini (Berkeley 1994). 
Okamura L. (1996) "Roman withdrawals from three transfluvial frontiers", in Shifting Frontiers in Late Antiquity, edd. R. W. Mathisen and H. S. Sivan (Aldershot 1996) 11-19.

Pearson A. F. (2002) The Roman Shore Forts: Coastal Defences of Southern Britain (Stroud 2002).

Pollini J. (2006) Review of Varner, Mutilation and Transformation: Damnatio Memoriae and Roman Imperial Portraiture in The Art Bulletin 88.3 (Sept. 2006) 590-98.

Poulter A. G. (2007a) ed. The Transition to Late Antiquity: on the Danube and Beyond (Proceedings of the British Academy 141) (London 2007).

(2007b) "The transition to Late Antiquity", in The Transition to Late Antiquity: on the Danube and Beyond, ed. A. G. Poulter (Proceedings of the British Academy 141) (London 2007) 1-50.

Rambaldi S. (2009) L'edilizia pubblica nell'impero romano all'epoca dell'anarchia militare (235-284 d.C.) (Bologna 2009).

Reece R. (1999a) The Later Roman Empire: an Archaeology AD 150-600 (Stroud 1999). (1999b) “Two late Roman cemeteries in Italy", JRA 12 (1999) 793-97.

Rinaldi Tufi S. (2005) "La grande architettura fra Diocleziano e Costantino a Roma e nel mondo romano", in Costantino in Grande: La civilità antica al bivio tra Occidente e Oriente, edd. A. Donati and G. Gentili (Milan 2005) 92-105.

Sauer E. (2003) The Archaeology of Religious Hatred in the Roman and Early Medieval World (Stroud 2003).

Schmid S. (2001) "Worshipping the emperor(s): a new temple of the imperial cult at Eretria and the ancient destruction of its statues", JRA 14 (2001) 113-42.

Snyder C. A. (1998) An Age of Tyrants: Britain and the Britons, A.D. 400-600 (Stroud 1998).

Southern P. and Dixon K. R. (1996) The Late Roman Army (London 1996).

Swain S. and Edwards M. (2004) edd. Approaching Late Antiquity: the Transformation from Early to Late Empire (Oxford 2004).

Tlass M. (1986) Zénobie: Reine de Palmyre (Damas 1986).

Tomlin R. S. O. (2000) "The legions in the late Empire", in Roman Fortresses and their Legions, ed. R. Brewer (London 2000) 159-79.

(2006) "The owners of the Beaurains (Arras) treasure", in Constantine the Great: York's Roman Emperor, edd. E. Hartley, J. Hawkes, M. Henig and F. Mee (York 2006) 59-64.

Ulbert Th. (1981) Ad Pirum (Hrušica), Spätrömische Passbefestigung in den Julischen Alpen: Der deutsche Beitrag zu den slowenisch-deutschen Grabungen 1971-1973 (Munich 1981).

Van Ossel P. and Ouzoulias P. (2000) "Rural settlement economy in Northern Gaul in the late Empire: an overview", JRA 13 (2000) 133-60.

Vansittart P. (1983) Three Six Seven, Memoirs of a Very Important Man (London 1983).

Varner E. R. (2004) Mutilation and Transformation: Damnatio Memoriae and Roman Imperial Portraiture (Leiden 2004).

Ward-Perkins B. (2005) The Fall of Rome and the End of Civilization (Oxford and New York 2005).

Whitby M. (2004) "Emperors and armies, AD 235-395", in Approaching Late Antiquity: the Transformation from Early to Late Empire, edd. S. Swain and M. Edwards (Oxford 2004) 156-86.

White R. (2007) Britannia Prima: Britain's Last Roman Province (Stroud 2007).

Wightman E. (1981) "The fate of Gallo-Roman villages in the third century", in The Roman West in the Third Century: Contributions from Archaeology and History, edd. A. King and M. Henig (Oxford 1981) 235-43.

Witschel C. (2004) "Re-evaluating the Roman West in the 3rd c. A.D.", JRA 17 (2004) 251-81.

Yon J.-B. (2001) "Euergetism and urbanism in Palmyra", in Recent Research in Late-Antique Urbanism, ed. L. Lavan (JRA Supplementary Series 42) (Portsmouth, RI 2001) 173-81.

\section{LIST OF FIGURES}

Fig. 1. The canal defensive walls at Aquileia in north-east Italy. The multiple defences at this imperial city are assigned to various historical dates, many tied to civil war episodes. The image shows spolia as the main wall fabric, perhaps indicative in this instance of rushed works in advance of expected assault. (Photo: Neil Christie)

Fig. 2. A 19th-c. engraving of Burgh Castle wall and circuit tower, one of the Saxon Shore fort installations active by the final quarter of the 3rd c. (Image by Knight (1845)).

Fig. 3. Dedication in the Rome Forum set up by the city Prefect Pisidius Romulus in A.D. 405. Above the SPQR, the two lines which formerly heralded the name of the magister militum Stilicho have seen damnatio memoriae imposed following the Emperor Honorius' execution of his general in A.D. 408. (Photo: Pauline Carroll)

Fig. 4. The Arch of Constantine, Rome-view of the south face, left entrance arch, depicting the siege by Constantine's troops of Verona (or Susa) in north Italy; above are two of the roundels of Hadrianic date. (Photo: Neil Christie). 
Fig. 5. AR antoninianus of Postumus (259-68). 19 x $23 \mathrm{~mm}, 3.13 \mathrm{~g}$.

Mint: Mint city I (Treveri [Trier]), 1st officina. Struck: 1st emission, 1st phase, AD 260. Obv: IMP C M CASS LAT POSTIMVS P F AVG Radiate, draped, and cuirassed bust right.

Rev: SALVS PROVINCIARVM River god Rhinus reclining left, resting right arm on forepart of boat left in background, cradling reed in left arm, which rests against urn to right. The river god and warship may well symbolise the riverine and maritime strength of the 'Gallic Empire'. Ref: Mattingly-Sydenham, RIC 587 corr. (obv. legend); AGK 87a; Cunetio 2367 (Source: http://classicaleconomies.com/mil_anarchy.shtml).

Fig. 6a and b. Billion antonianus of Vabalathus (268-72). 20 mm, Mint: Antiochia 272.

Obv: IMP C AVRELIANVS AVG/H Radiate, draped, and cuirassed bearded bust of Aurelianus right. Rev: VABALATHVS V C R IM D R Laureated, draped bust of Vabalthus right.

Ref: Mattingly-Sydenham, RIC 5381 (Copyright image Andreas Pangerl, www.romancoins.info). 